\title{
Simulation Analysis of the Four Configurations of Solar Desiccant Cooling System Using Evaporative Cooling in Tropical Weather in Malaysia
}

\author{
M. M. S. Dezfouli, ${ }^{1}$ S. Mat, ${ }^{1}$ G. Pirasteh, ${ }^{2}$ K. S. M. Sahari, ${ }^{3}$ K. Sopian, ${ }^{1}$ and M. H. Ruslan ${ }^{1}$ \\ ${ }^{1}$ Solar Energy Research Institute (SERI), Universiti Kebangsaan Malaysia, 43600 Bangi, Selangor, Malaysia \\ ${ }^{2}$ Department of Mechanical Engineering, Faculty of Engineering, University of Malaya, 50603 Kuala Lumpur, Malaysia \\ ${ }^{3}$ Department of Mechanical Engineering, Universiti Tenaga Nasional, Jalan IKRAM-UNITEN, 43000 Kajang, Selangor, Malaysia \\ Correspondence should be addressed to M. M. S. Dezfouli; salehi.solar@gmail.com
}

Received 29 May 2013; Revised 13 November 2013; Accepted 29 November 2013; Published 2 February 2014

Academic Editor: Ismail H. Altas

Copyright (C) 2014 M. M. S. Dezfouli et al. This is an open access article distributed under the Creative Commons Attribution License, which permits unrestricted use, distribution, and reproduction in any medium, provided the original work is properly cited.

\begin{abstract}
A high demand for air conditioning systems exists in hot and humid regions because of the warm climate during the year. The high energy consumption of conventional air conditioning system is the reason for our investigation of the solar desiccant cooling system as an energy-efficient cooling system. Four model configurations were considered to determine the best configuration of a solar desiccant cooling system: one-stage ventilation, one-stage recirculation, two-stage ventilation, and two-stage recirculation. These models were stimulated for $8,760 \mathrm{hr}$ of operation under hot and humid weather in Malaysia. Several parameters (i.e., coefficient of performance or COP, room temperature and humidity ratio, and the solar fraction of each system) were evaluated by detecting the temperature and humidity ratio of the different points of each configuration by TRNSYS simulation. The latent and sensible loads of the test room were $0.875 \mathrm{~kW}$ and $2.625 \mathrm{~kW}$, respectively. By investigating the simulation results of the four systems, the ventilation modes were found to be higher than the recirculation modes in the one- and two-stage solar desiccant cooling systems. The isothermal dehumidification COP of the two-stage ventilation was higher than that of the two-stage recirculation. Hence, the two-stage ventilation mode desiccant cooling system in a hot and humid area has higher efficiency than the other configurations.
\end{abstract}

\section{Introduction}

Because of the high electrical consumption of conventional vapor compression systems, the solar desiccant cooling system has been considered as one of the promising alternatives to cooling air where the sensible and latent heats of air are removed separately [1]. The first desiccant cooling system was presented by Pennington in 1955 [2]. Generally, depending on the dehumidification material used, two kinds of desiccant cooling system exist: solid and liquid. Many scientists and researchers have studied both kinds of desiccant cooling using renewable energy [3]. The common materials used in the solid and liquid desiccant cooling systemwere silica gel and liquid water-lithium chloride. The desiccant cooling system includes three main units, namely, desiccant, heat-source, and cooling units [4]. The elements of each unit are designed depending on the weather conditions. The components of the basic cycle consist of the solid desiccant wheel (DW) as dehumidifier, evaporative cooler as the cooling unit, and the heat recovery wheel as the heater and cooler in the regeneration and process air sides, respectively. In recent years, according to the Pennington cycle, different types of solid desiccant cooling cycles have been designed in the world by different researchers. The coefficient of performance (COP) of the desiccant cooling system, regeneration temperature, mass flow rate, fresh air, and relative humidity of the supply air are the important parameters considered by the researchers. Haddad et al. [5] studied the simulation of a desiccant-evaporative cooling system for residential buildings. They found that the use of solar energy for regeneration of the DW can provide a significant portion of the auxiliary thermal energy needed. 
Fong et al. [6] designed a simulation model (TRNSYS) of an integrated radiant cooling by absorption refrigeration and desiccant dehumidification. Salehi Dezfouli et al. [7] investigated the solar hybrid desiccant cooling system in hot and humid weather in Malaysia. They found that a solar hybrid solid desiccant cooling system provided considerable energy savings in comparison with the conventional vapor compression in hot and humid area.

Researchers have studied and compared the COP of ventilation and recirculation cycles. Jain et al. [8] evaluated ventilation and recirculation cycles based on weather data in India to determine the effectiveness of evaporative coolers on the COP of a cooling system. Boundoukan et al. [9] evaluated a comparison between ventilation and recirculation procedure modes; critical values were achieved for cycle component performance specifics required to yield a given supply air temperature condition. Mehmet et al. [10] evaluated First low and second Low for COPs of ventilation and recirculation cycles. Panaras et al. [11] investigated the behavior of the COP of the ventilation and recirculation desiccant cooling systems in terms of the air flow rate. They found that the ventilation cycle presents a higher COP, and the required air flow rate is similar for both cycles. Sphaier et al. [12] studied the simulation of ventilation and recirculation desiccant cooling systems to analyze the impact of cycle component characteristics on the overall system performance. They concluded that, although all components can influence the COP, the COP values of the recirculation cycle are lower than the ventilation cycle.

With regard to the increase in temperature of the process air after dehumidification and the limitation capacity of the dehumidification by the DW, the required regeneration temperature is high, especially in hot and humid regions [13-16]. Many researchers have attempted to determine the best solution for the high required regeneration temperature problem in one-stage desiccant cooling systems. The isothermal dehumidification process is a great solution to solve this problem. The required cool process air after dehumidification and reduced regeneration temperature can be obtained using isothermal dehumidification technology or multistage dehumidification process. Meckler [17] proposed a two-stage solid desiccant air conditioning system integrated with an HVAC system. A two-stage system was also introduced by Henning [18]. A novel rotary desiccant cooling cycle with isothermal dehumidification and regenerative evaporative cooling was proposed by La et al. [19]. They found that the isothermal dehumidification was relatively lower temperature requirement for the heat source because the regeneration temperature is reduced from $80^{\circ} \mathrm{C}$ to approximately $60^{\circ} \mathrm{C}$. $\mathrm{Ge}$ et al. [20] evaluated the performance of a two-stage rotary desiccant cooling (TSRDC) system. The required regeneration temperature of the TSRDC system is low, and the COP of the system is high. La et al. [21] performed a theoretical analysis of a solar-driven TSRDC system assisted by vapor compression air conditioning. They concluded that the solar-driven two-stage desiccant cooling system is reliable and energy efficient. Li et al. [22] investigated the TSRDC/heating system driven by evacuated glass tube solar air collectors. Their experimental results indicated that the average thermal COP in the cooling cycle was 0.97 , and the cooling capacity was in the range from $16.3 \mathrm{~kW}$ to $25.6 \mathrm{~kW}$ under hot and humid ambient conditions. Li et al. [23] carried out experimental investigation on a one-rotor twostage desiccant cooling/heating system driven by solar air collectors. The average thermal COP in the cooling cycle is 0.95 in hot and humid climate conditions.

Given the use of ambient air in solar desiccant cooling systems, the ambient conditions of each region have a significant impact on system performance. Although various studies and publications on the one-stage and two-stage desiccant cooling systems have been based on different weather data, no such study compares one-stage and two-stage solar cooling technologies that have been undertaken in Malaysia. The high demands of air conditioning systems because of hot and humid weather during the year, as well as the high energy consumption of conventional AC systems, have resulted in the investigation of the solar desiccant cooling system as an efficient air conditioning system in Malaysia. The present paper presents a comparison simulation study among the four configurations of solar desiccant cooling system in hot humid weather in Malaysia.

\section{Methodology}

The comparison performance between the one-stage and two-stage solar desiccant cooling systems under the ventilation and recirculation modes is used as the methodology in this study. The one-stage and two-stage desiccant cooling systems are explained in the following sections.

2.1. Case Study Description. Four kinds of solar desiccant cooling systems were considered to supply air for a test room in a technology park (UKM) in Malaysia. The onestage desiccant cooling system under two modes of ventilation and recirculation and the two-stage desiccant cooling system under two modes of ventilation and recirculation were considered to evaluate the four types of desiccant cooling system. The latent and sensible loads of the test room were 0.875 and $2.625 \mathrm{~kW}$, respectively. The cooling capacity was 1 ton. According to the American Society of Heating, Refrigerating and Air Conditioning Engineers (ASHRAE) comfort condition, indoor condition designs should consist of temperature of $25^{\circ} \mathrm{C}$, relative humidity of $50 \%$, and humidity ratio of $0.0098 \mathrm{~kg} / \mathrm{kg}$ [24]. According to the Malaysian weather, in outdoor condition design, the temperature should be $30^{\circ} \mathrm{C}$, and the humidity ratio should be $0.0200 \mathrm{~kg} / \mathrm{kg}$. The cooling system includes four main parts, namely, DW as dehumidifier, heat recovery wheel, evaporative cooler as humidifier, and solar-evacuated tube collector as heat source. Simulation design using the TRNSYS software was carried out to investigate the solar desiccant cooling in the different configurations to find the best operation of the components and the cooling system based on the hot and humid weather in Malaysia. In this study, one stage (ventilation and recirculation modes) and two stages (ventilation and recirculation modes) were simulated under the same effectiveness of the components. 
TABLE 1: Specific assumptions used in simulation.

\begin{tabular}{ll}
\hline Item & Factor \\
\hline DW & Type $683, F_{1}=0.1, F_{2}=0.07$, power consumption: $0.2 \mathrm{~kW}$, and speed of rotor rotation: $8 \mathrm{r} / \mathrm{h}$ \\
DEC & Type $506 \mathrm{c}$, saturation efficiency $=0.8$, and power consumption: $0.1 \mathrm{~kW}$ \\
& Type $760 \mathrm{~b}$, sensible efficiency $=75.6 \%$, latent efficiency $=0 \%$, and power consumption: \\
HRW & $0.17 \mathrm{~kW}$ \\
& Type 91 , effectiveness $=0.7$, specific heat of hot side: $4.19 \mathrm{kj} / \mathrm{kg} \cdot \mathrm{K}$, and specific heat of hot \\
HX & side: $1.05 \mathrm{kj} / \mathrm{kg} \cdot \mathrm{K}$ \\
Pump & Type $3 \mathrm{~b}$, maximum power consumption: $60 \mathrm{~W}$ and water flow rate: $180 \mathrm{~kg} / \mathrm{h}$ \\
Blower & Type $112 \mathrm{a}$, motor efficiency $=0.85$ and maximum air flow rate: $870.4 \mathrm{~kg} / \mathrm{h}$ \\
Room (load) & Type 690 , sensible load: 2.625, latent load: 0.875, SHR $=0.75$ \\
Weather data & Type $109-\mathrm{TMY} 2$, all of weather data is based on Kuala Lumpur $(\mathrm{Malaysia)}$ \\
Solar collector & Type 71, evacuated tube, area of collector: $20 \mathrm{~m}{ }^{2}$ and the efficiency of collector $\eta: 0.60$ \\
Hot water tank & Type $4 \mathrm{c}$, the loss coefficient: $0.55 \mathrm{~W} / \mathrm{m}^{2} \mathrm{~K}$ \\
Backup heater & Type 6 , the maximum heating rate: $10 \mathrm{~kW}$ \\
$G$ & The one year average solar radiation of Malaysia $(2012): 500 \mathrm{~W} / \mathrm{m}^{2}$ \\
\hline
\end{tabular}

In the simulation process, the regeneration temperature can be detected by adjusting and setting the required humidity ratio after the dehumidification process in DW as the humidity ratio set point. Three set points (i.e., 0.0100, 0.0080, and $0.0050 \mathrm{~kg} / \mathrm{kg}$ ) for the humidity ratio were considered for the one-stage ventilation and recirculation modes to evaluate the behavior of regeneration temperatures and COPs. In a comparative evaluation between one-stage and two-stage solar desiccant cooling systems, the humidity ratio set points for the first and second DW in the two-stage ventilation and recirculation modes were $0.0100 \mathrm{~kg} / \mathrm{kg}$ and $0.0050 \mathrm{~kg} / \mathrm{kg}$, respectively. The properties of the simulation components used in the four configurations are shown in Table 1. The solar desiccant cooling system was divided into two parts, namely, the one-stage and the two-stage that are explained in Sections 2.2 and 2.3, respectively. The TRNSYS simulation was validated by the measurement data from the experimental setup of the one-stage ventilation solar desiccant cooling system. This system had been installed in the technology park at the Universiti Kebangsaan Malaysia [7]. After the validation of TRNSYS, it was used to simulate the four configurations of the solar desiccant cooling system.

2.2. One-Stage Solar Desiccant Cooling System. The one-stage solar desiccant cooling includes the ventilation and recirculation modes. The components of the one-stage desiccant cooling are one DW, one heat recovery wheel, two evaporative coolers, one heat exchanger, one auxiliary heater, and an evacuated tube collector.

The air flow rate of the one-stage ventilation and recirculation in the process and regeneration sides of the system was $870.4 \mathrm{~kg} / \mathrm{hr}$.

2.2.1. One-Stage Ventilation Mode. Figure 1 shows that the ventilation mode of the solar desiccant cooling is an open cycle that provides supply air to the room from ambient air.

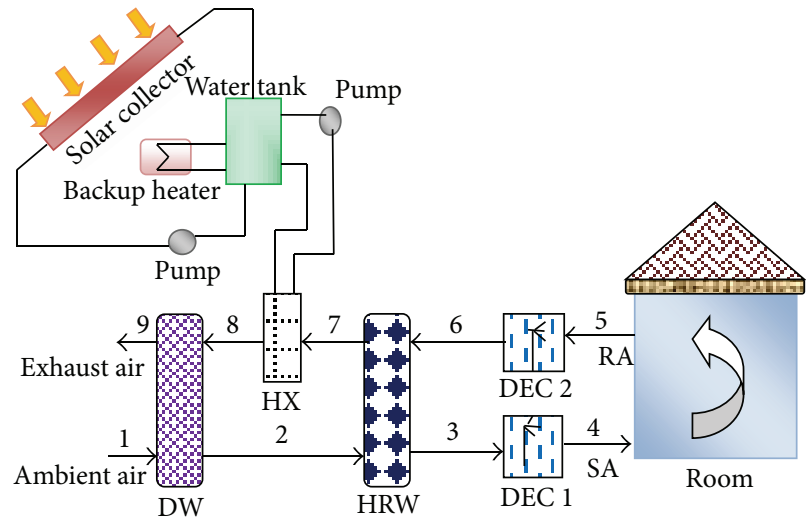

FIGURE 1: Solar desiccant cooling in ventilation mode schematic.

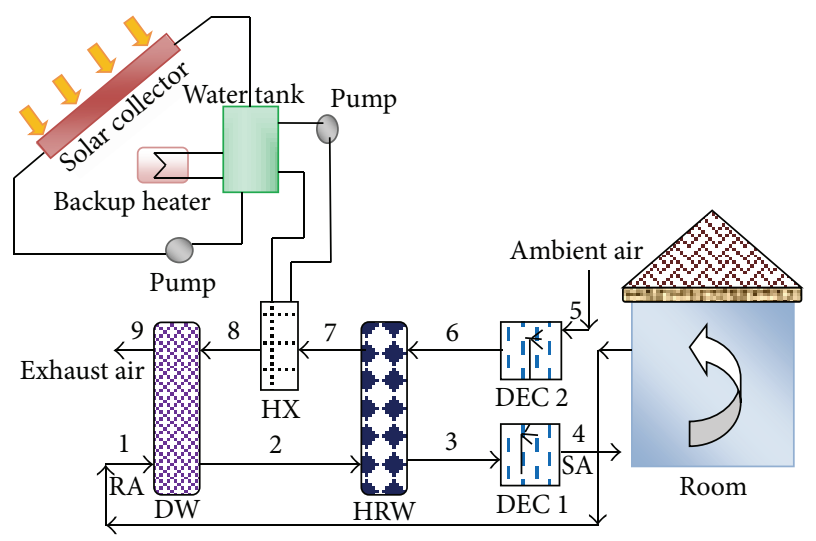

FIGURE 2: Solar desiccant cooling in recirculation mode schematic.

The returning air from the room after few processes is converted to ambient temperature as exhaust air. Therefore, two kinds of air are present: the process side that produces 


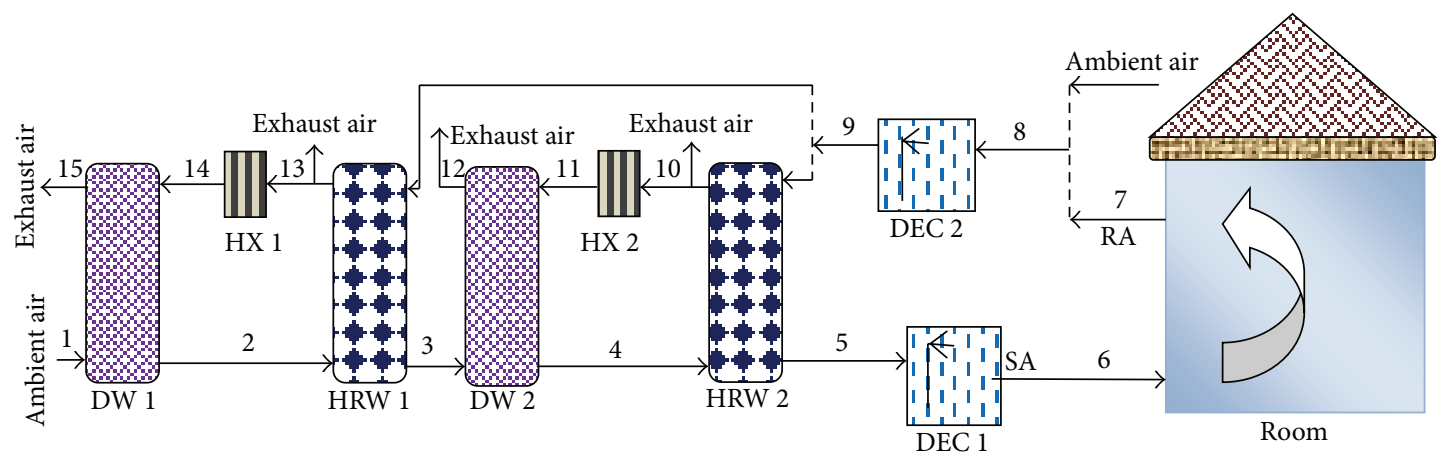

FIGURE 3: Schematic of two-stage solar desiccant cooling system-ventilation mode.

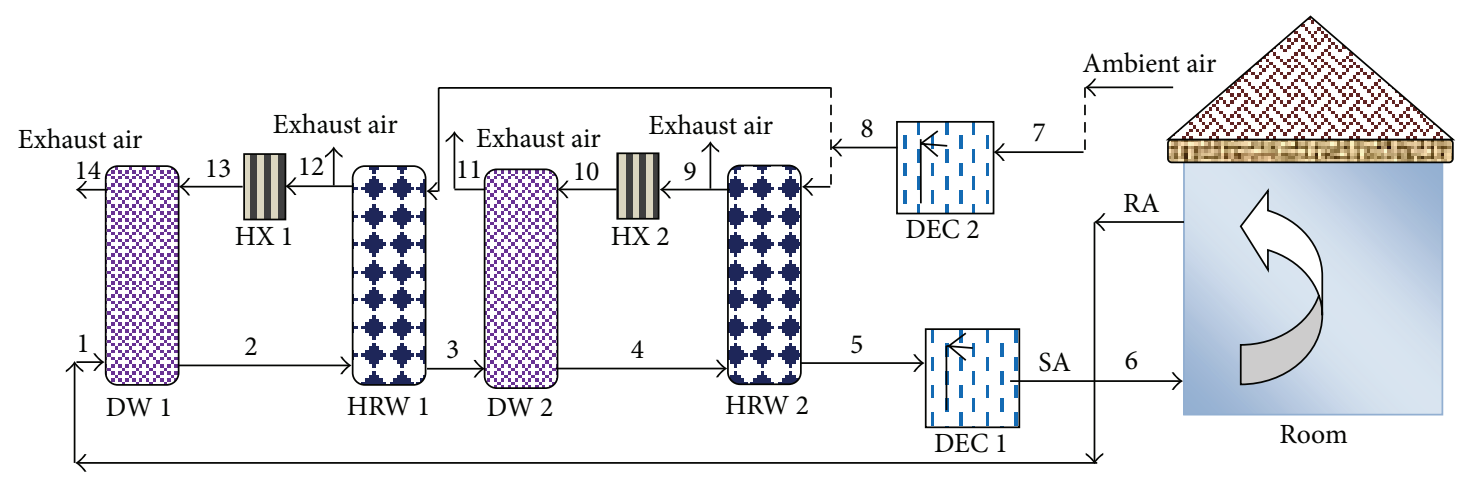

FIGURE 4: Schematic of two-stage solar desiccant cooling system-recirculation mode.

the supply air, and the regeneration side that releases the returning air from room to ambient temperature. In the process side, first, the ambient air becomes dry because of the DW. Then, the heat recovery wheel cools the air in the process side. In the next step, the air becomes cold because of the evaporative cooler; then, the air moves into the room as supply air. In the regeneration side, the returning air whose latent and sensible loads were left in the room becomes cold because of the evaporative cooler. The heat recovery wheel acts as an energy conservation wheel in the regeneration air side. Then, the heat from the heat exchanger is transferred to the air. In the last step in the regeneration side, the hot air thus absorbed the humidity of the DW and released it outside.

2.2.2. One-Stage Recirculation Mode. Figure 2 shows the recirculation mode of the solar desiccant cooling system. Generally, this system is not an open cycle. The process air side in the recirculation mode is a closed loop, whereas the regeneration air side is an open cycle.

In the process air side, the room air that includes the sensible and latent loads moves to the DW to remove the latent load. The heat recovery wheel acts as a cooler in the process air side. In the next step, the air grows cold because of the evaporative cooler, and it moves into the room as supply air. In the regeneration side, the ambient air grows cold because of the evaporative cooler. In the next step, the heat from the solar collectors and the backup heater is transferred to the air by means of a heat exchanger. Thus, in the last step in the regeneration side, the hot air absorbs the humidity of the DW and is released as exhaust air outdoors.

2.3. Two-Stage Solar Desiccant Cooling System. The two-stage solar desiccant cooling includes the ventilation and recirculation modes. The components of the two-stage desiccant cooling system are two DWs, two heat recovery wheels, two evaporative coolers with different capacities, two heat exchangers, two auxiliary heaters, and an evacuated tube collector. According to the high dehumidification capacity of the two-stage DW and the humid weather in Malaysia, the set point of dehumidification was adjusted at a $0.0050 \mathrm{~kg} / \mathrm{kg}$ humidity ratio. The air flow rate of the two-stage ventilation and recirculation in the process side was $870.4 \mathrm{~kg} / \mathrm{hr}$ and $435.2 \mathrm{~kg} / \mathrm{hr}$ in the regeneration side.

2.3.1. Two-Stage Ventilation Mode. Figure 3 shows the twostep dehumidification of the process air in the solar desiccant cooling system using the evaporative cooling units in ventilation mode. This mode is an open cycle. The air properties of each of the 15 points are characterized by the simulation model. The air properties are explained in Section 3.

The supply air in the process side is produced from the ambient air by undergoing a few stages, such as the twostep dehumidification in the DWs (2 and 4), two-step cooling in the heat recovery wheels (3 and 5), and one-step cooling in the direct evaporative cooler (6). In the regeneration air side, the returning air (7) is mixed with the ambient air (8) 


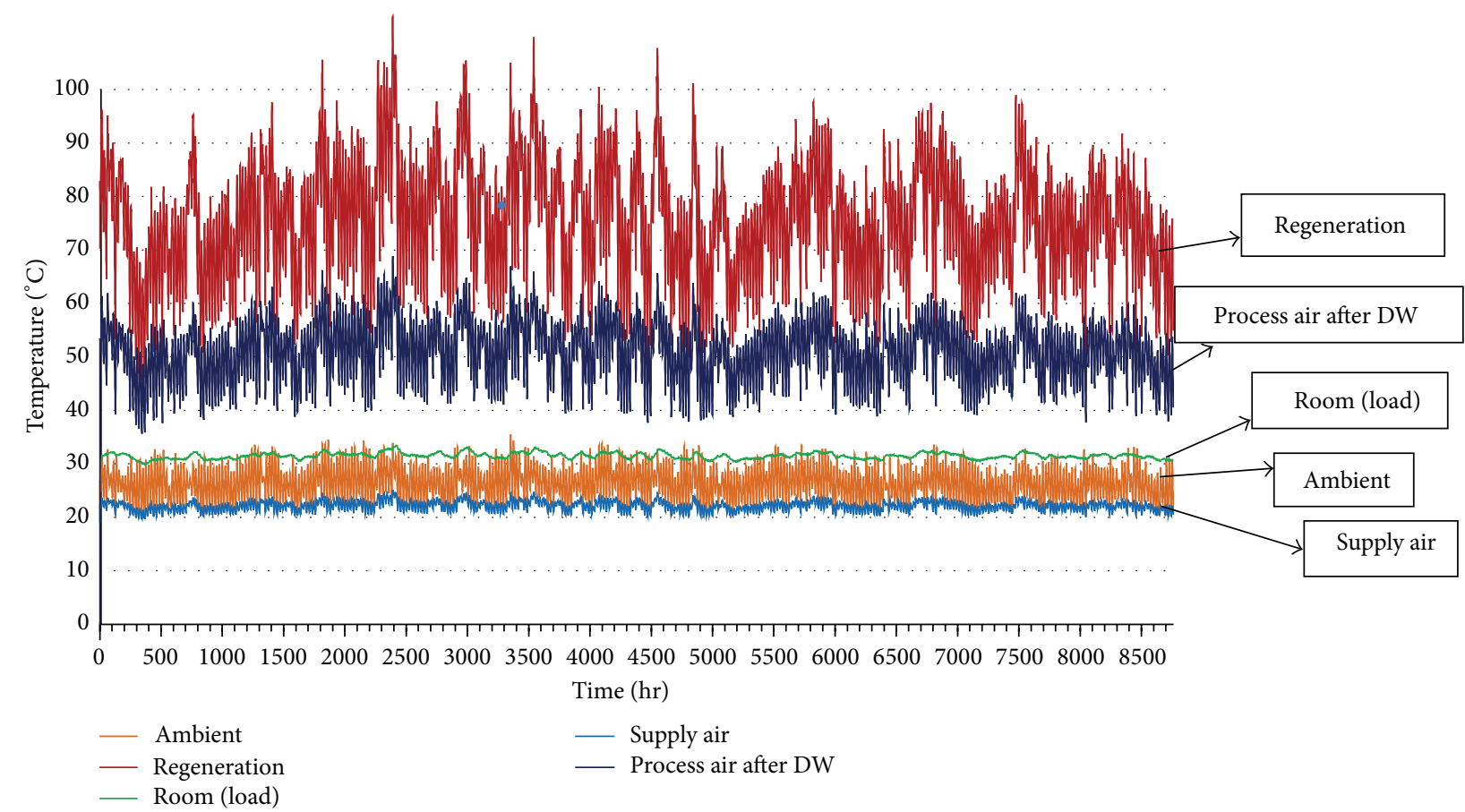

Figure 5: Temperatures $\left({ }^{\circ} \mathrm{C}\right)$ of different components versus time $(\mathrm{hr})$ in ventilation desiccant cooling system.

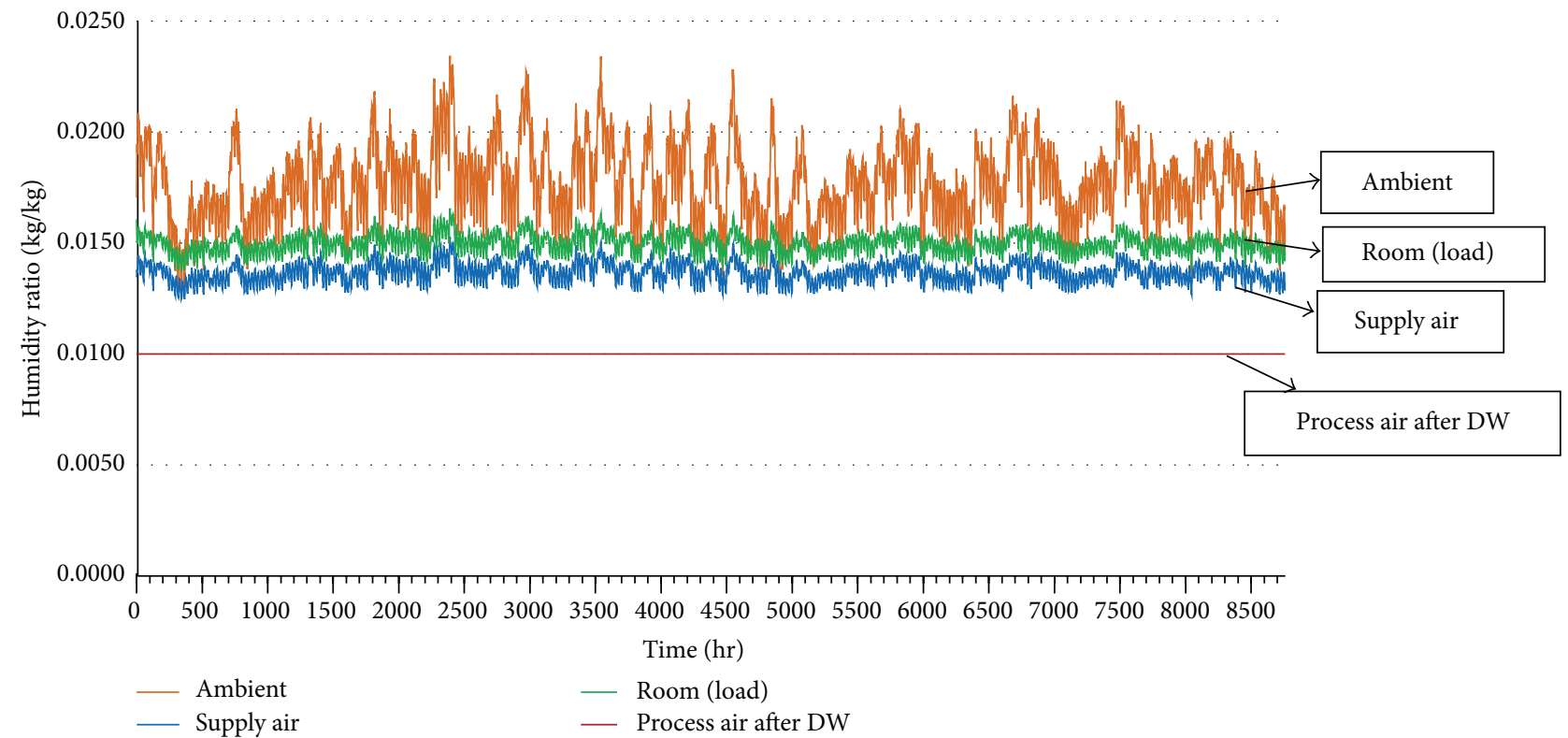

FIGURE 6: Humidity ratio (kg/kg) of different components versus time (hr) in ventilation desiccant cooling system.

before being cooled in one direct evaporative cooler. Then, the output air from the evaporative cooler (9) is divided into two stages with the same air flow rate. In each stage, air is heated in the heat recovery wheel (10 and 13), heated in the solar heaters (11 and 14), and humidified in the DWs (12 and $15)$.

2.3.2. Two-Stage Recirculation Mode. Figure 4 shows the schematic of the two-stage solar desiccant cooling system under the recirculation mode. The process air side (1-6) is a closed loop and the regeneration side (7-14) is an open cycle. Supply air is produced from the returning air in the process air side by undergoing a few stages, such as the twostep dehumidification in the DWs (2 and 4), two step cooling in the heat recovery wheels ( 3 and 5), and one-step cooling in the direct evaporative cooler (6). In the regeneration side, ambient air (7) is mixed from the air in the cooler (8) and then divided into two stages for the heating and humidifying 
process (8-11 and 8-14). The process air under the ventilation mode is an open loop, whereas it is a closed loop under the recirculation mode.

2.4. Determination of the COP of the Desiccant Cooling System. The COP of the solar desiccant cooling system can be calculated by the rate of heat extracted against the rate of the cooling system driving energy. The rate of heat extracted is the cooling capacity of the system. The rate of the cooling system driving energy is the total thermal energy requirement for the cooling system generated from solar collectors and the backup heater. Therefore, the COP of the system is obtained by the following relationship [4]:

$$
\mathrm{COP}=\frac{Q_{\text {cool }}}{Q_{T}}
$$

2.4.1. One Stage. The COP of the solar desiccant cooling system under the ventilation mode is defined as the ratio of the enthalpy change from ambient air to supply air, multiplied by the mass air flow and external heat delivered to the regeneration heat exchanger. It can be written as follows:

$$
\mathrm{COP}=\frac{\dot{m}_{s}\left(h_{1}-h_{4}\right)}{\dot{m}_{r}\left(h_{8}-h_{7}\right)}
$$

The COP of the solar desiccant cooling under recirculation mode can be written as

$$
\mathrm{COP}=\frac{\dot{m}_{s}\left(h_{1}-h_{4}\right)}{\dot{m}_{r}\left(h_{8}-h_{7}\right)},
$$

where $\dot{m}_{s}(\mathrm{~kg} / \mathrm{hr})$ is the mass flow rate of the supply air, $\dot{m}_{r}$ $(\mathrm{kg} / \mathrm{hr})$ is the mass flow rate of the regeneration air, and $h$ $(\mathrm{kJ} / \mathrm{kg})$ is the enthalpy of air.

2.4.2. Two Stages. The COP of the two-stage solar desiccant cooling under the ventilation mode can be written as [20]

$$
\mathrm{COP}=\frac{\dot{m}_{s 1}\left(h_{1}-h_{6}\right)}{\dot{m}_{r 13}\left(h_{14}-h_{13}\right)+\dot{m}_{r 10}\left(h_{11}-h_{10}\right)} .
$$

The COP of the two-stage solar desiccant cooling under the recirculation mode can be written as

$$
\mathrm{COP}=\frac{\dot{m}_{s 1}\left(h_{1}-h_{6}\right)}{\dot{m}_{r 12}\left(h_{13}-h_{12}\right)+\dot{m}_{r 9}\left(h_{10}-h_{9}\right)},
$$

where $\dot{m}_{s}(\mathrm{~kg} / \mathrm{hr})$ is the mass flow rate of the supply air, $\dot{m}_{r}$ $(\mathrm{kg} / \mathrm{hr})$ is the mass flow rate of the regeneration air, and $h$ $(\mathrm{KJ} / \mathrm{kg})$ is the enthalpy of air.

2.5. Solar Fraction. Generally, solar collectors convert solar radiation into thermal energy in solar cooling systems. Considering the insufficient thermal energy from solar collectors in cloudy weather, the backup heater is used to achieve the required thermal energy for the total cooling system driving energy. The percentage ratio of the thermal energy produced by the solar collectors to the total cooling system driving
TABLE 2: Air properties of one-stage solar desiccant cooling system in ventilation mode.

\begin{tabular}{lcc}
\hline Points number & Temperature $\left({ }^{\circ} \mathrm{C}\right)$ & Humidity ratio $(\mathrm{kg} / \mathrm{kg})$ \\
\hline 1 & 30 & 0.0200 \\
2 & 49.5 & 0.0100 \\
3 & 31.8 & 0.0100 \\
4 & 22 & 0.0137 \\
5 & 30.8 & 0.0152 \\
6 & 24.95 & 0.0176 \\
7 & 45.6 & 0.0176 \\
8 & 81.6 & 0.0176 \\
9 & 50 & 0.0262 \\
\hline
\end{tabular}

energy is known as the solar fraction, which can be expressed as follows [25]:

$$
\mathrm{SF}=\frac{\mathrm{Q}_{U}}{\mathrm{Q}_{T}},
$$

where $Q_{T}$ is the total cooling system driving energy produced by the solar collectors and the backup heater. $Q_{U}$ is the thermal energy produced by the solar collectors that can be expressed as [26]

$$
Q_{U}=A \times \eta \times G
$$

\section{Results and Discussion}

The results of the four different systems were explained and then compared in the next sections. The temperature and humidity ratio against time of the specified points in the four systems were analyzed.

\subsection{Results of the One-Stage Solar Desiccant Cooling System}

3.1.1. Ventilation Mode. The temperature of ambient air, process air after the DW, supply air, room (load), and regeneration temperature versus time (hr) are shown in Figure 5. The temperatures at different points were specified for $8,760 \mathrm{~h}$ after running the solar desiccant cooling system. The regeneration temperature is one of the important parameters that play a main role in the changes in the COP of the desiccant cooling system. The regeneration temperature under the ventilation mode for $0.0100 \mathrm{~kg} / \mathrm{kg}$ dehumidification (humidity ratio reduction from $0.0200 \mathrm{~kg} / \mathrm{kg}$ to $0.0100 \mathrm{~kg} / \mathrm{kg}$ ) was almost $81.6^{\circ} \mathrm{C}$ (average). Figure 6 shows the humidity ratio of the ambient air, supply air, load, and process air after the DW versus time under the ventilation mode.

The humidity ratio of the supply air is one of the important parameters that play a main role in the amount latent load removed from the room by the desiccant cooling system, especially in hot and humid weather in Malaysia. The average temperature and humidity ratio of the specified points in the one-stage ventilation system for 8,760 h operation are shown in Table 2. The temperature and humidity ratio of the supply air (point 4) are $22^{\circ} \mathrm{C}$ and $0.0137 \mathrm{~kg} / \mathrm{kg}$, respectively, whereas those in the room (point 5) are $30.80^{\circ} \mathrm{C}$ and $0.0152 \mathrm{~kg} / \mathrm{kg}$, respectively. 


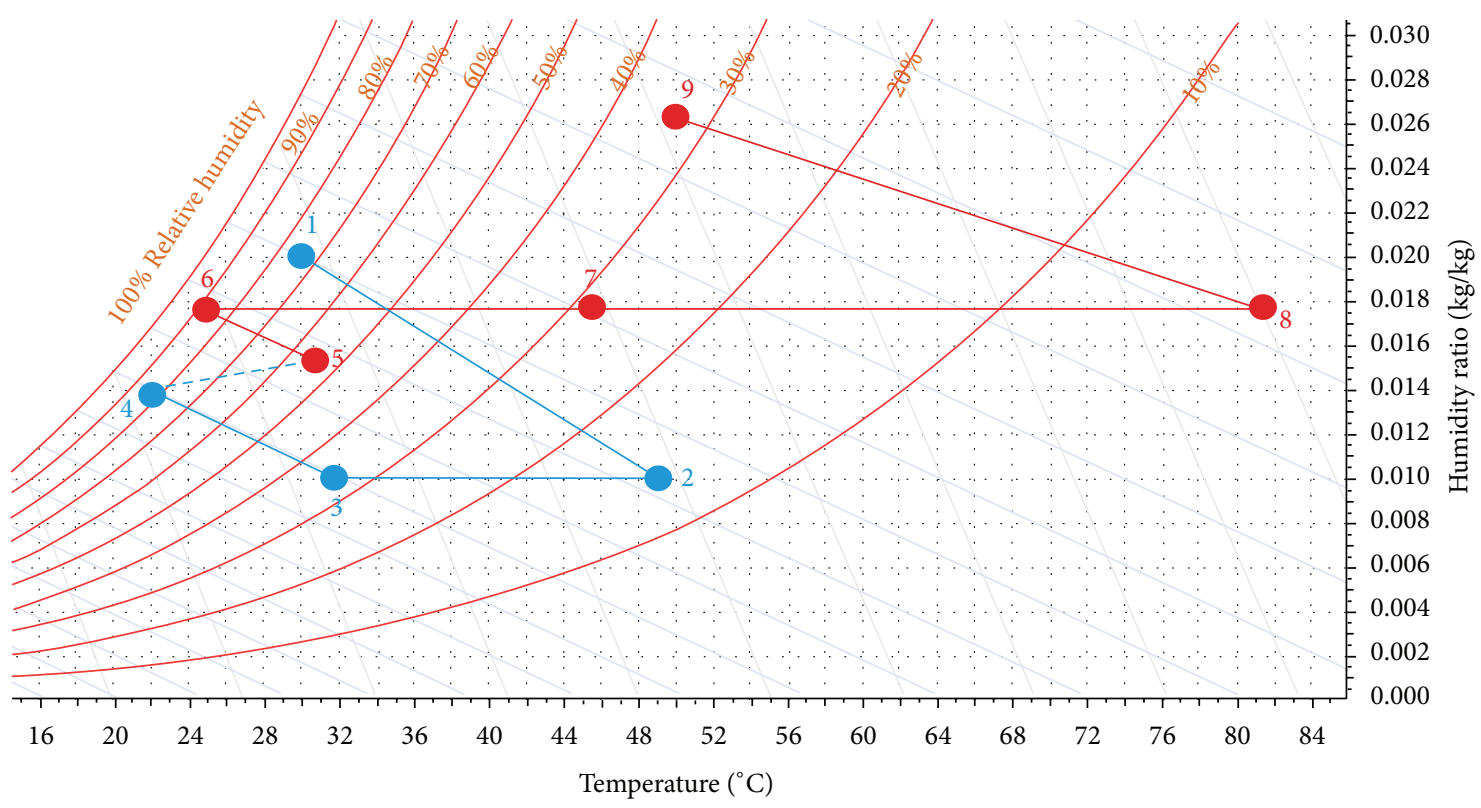

FIGURE 7: Psychometric chart of the one-stage solar desiccant cooling system under the ventilation mode.

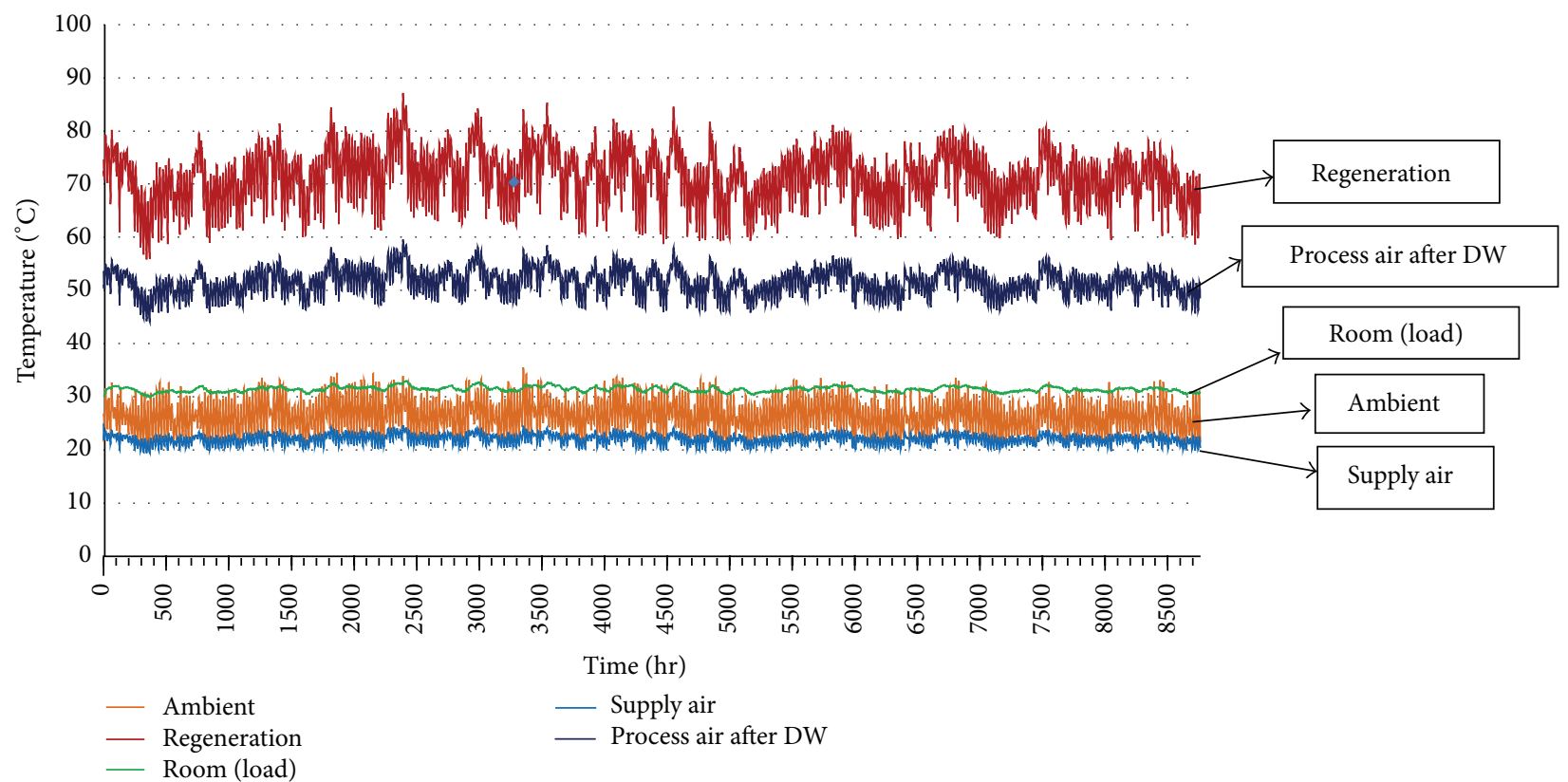

Figure 8: Temperatures $\left({ }^{\circ} \mathrm{C}\right)$ of different components versus time (hr) in recirculation desiccant cooling system.

Figure 7 shows the psychometric chart of the one-stage solar desiccant cooling system under the ventilation mode in which the air property and process air on all points are specified. The process-air and regeneration-air sides are indicated by blue and red lines, respectively. Because of the dehumidification process between points 1 and 2, the air temperature increases, whereas the humidity ratio decreases. By the cooling process between points 2 and 3, the air temperature decreases, whereas the humidity ratio of air in the heat recovery wheel remains constant. The temperature decreases, and the humidity ratio increases because of the evaporative cooling process between points 3 and 4 . The line between points 4 and 5 shows that the air property changes from supply air to the returning air inside the room. The regeneration side includes the four stages, namely, the evaporative cooling process between points 5 and 6 , heating between points 6 and 7, heating process between points 7 and 8 , and process of exhausted air to outdoor between points 8 and 9 .

3.1.2. Recirculation Mode. Figure 8 shows the temperatures $\left({ }^{\circ} \mathrm{C}\right)$ of the ambient air, process air after the DW, supply 


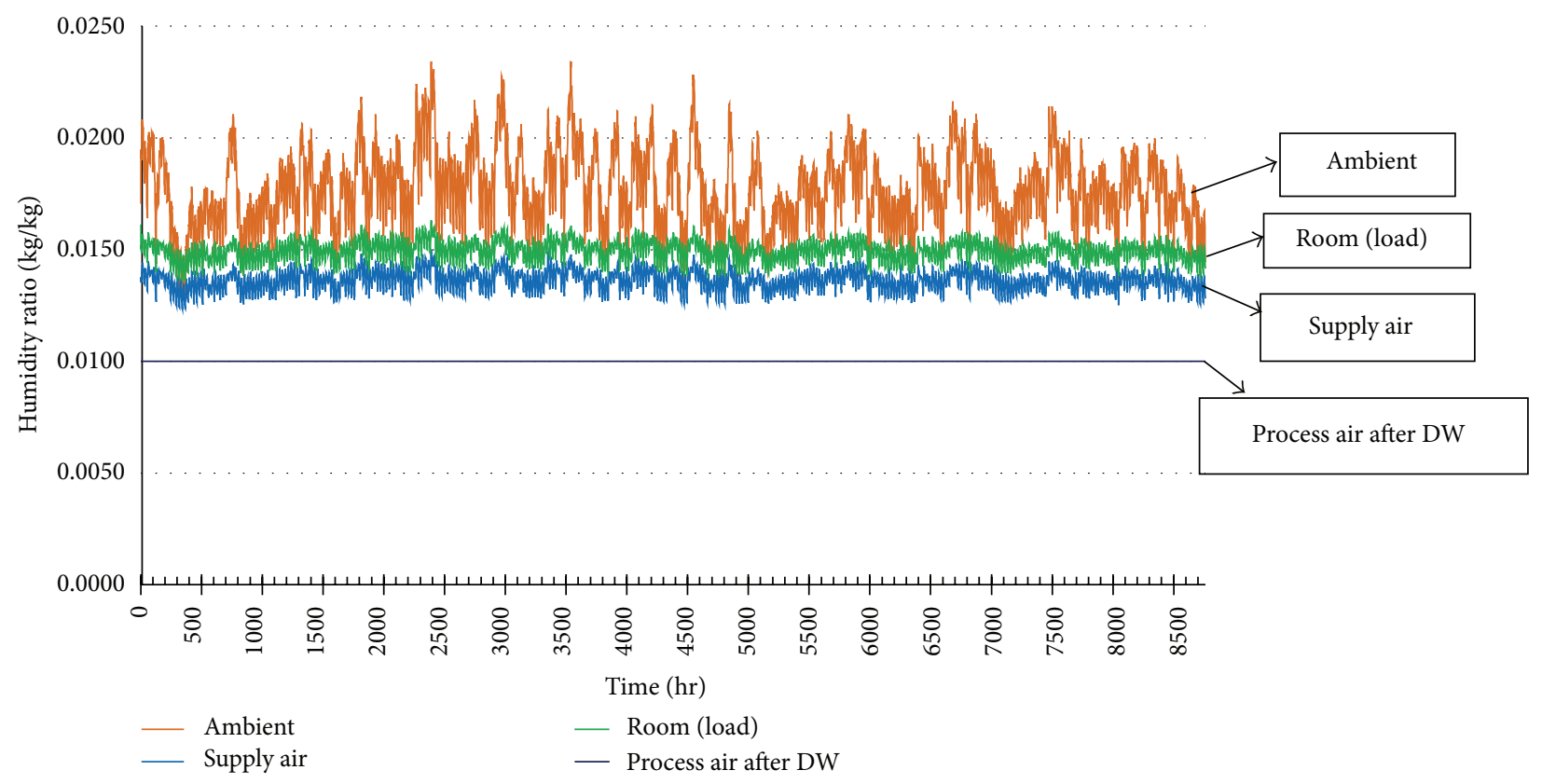

FIGURE 9: Humidity ratio $(\mathrm{kg} / \mathrm{kg})$ of different components versus time $(\mathrm{hr})$ in recirculation mode.

TABLE 3: Air properties of one-stage solar desiccant cooling system in recirculation mode.

\begin{tabular}{lcc}
\hline Points number & Temperature $\left({ }^{\circ} \mathrm{C}\right)$ & Humidity ratio $(\mathrm{kg} / \mathrm{kg})$ \\
\hline 1 & 31 & 0.0150 \\
2 & 51 & 0.0100 \\
3 & 31.4 & 0.0100 \\
4 & 21.4 & 0.0136 \\
5 & 30 & 0.0200 \\
6 & 26.4 & 0.0215 \\
7 & 45 & 0.0215 \\
8 & 70.2 & 0.0215 \\
9 & 55 & 0.0257 \\
\hline
\end{tabular}

air, the room, and the regeneration versus time (hr) under the recirculation mode. The regeneration temperature under the recirculation mode for $0.0100 \mathrm{~kg} / \mathrm{kg}$ dehumidification (humidity ratio reduced from $0.0200 \mathrm{~kg} / \mathrm{kg}$ to $0.0100 \mathrm{~kg} / \mathrm{kg}$ ) is almost $70.2^{\circ} \mathrm{C}$ (average). The humidity ratios of the ambient air and process air after DW, in the room, and the supply air versus time (hr) in the one-stage recirculation mode are shown in Figure 9.

The average temperature and humidity ratio of the specified points in the one-stage recirculation system for $8,760 \mathrm{~h}$ operation are shown in Table 3 . The temperature and humidity ratio of the supply air (point 4) are $21.4^{\circ} \mathrm{C}$ and $0.0136 \mathrm{~kg} / \mathrm{kg}$, respectively, whereas those for the room (point 1) are $31^{\circ} \mathrm{C}$ and $0.0150 \mathrm{~kg} / \mathrm{kg}$, respectively. Figure 10 shows the psychometric chart of the one-stage solar desiccant cooling system under the recirculation mode where the air property changes in the different parts of the solar desiccant cooling system are described. In the process side, the air returning from the room to the DW for dehumidification is shown between points 4 and 1 . The ambient air temperature is decreased by the evaporative cooling process ( 5 and 6 ). The heating process ( 6 and 7), heating process ( 7 and 8 ), and process of exhausted air to outdoor ( 8 and 9$)$ are performed in the regeneration side.

3.2. Comparison between the One-Stage Ventilation and Recirculation Modes. Table 4 shows the simulation results of the one-stage ventilation and recirculation modes in three different humidity ratio set points (i.e., 0.0050, 0.0080, and $0.0100 \mathrm{~kg} / \mathrm{kg}$ ). The results show that by increasing the humidity ratio set point in both modes, the trend of the regeneration temperature decreased, whereas the trend of supply air temperature, return air temperature, and COP increased. By increasing the humidity ratio set point because of the decreasing regeneration temperature, the COP of the system increased. The temperature and humidity of the room also increased. In the evolution of air conditioning system parameters, although the COP is the most important parameter, reaching the comfortable condition of the room is another important parameter that must be considered. For example, in ventilation mode, when the humidity ratio decreased from $0.00100 \mathrm{~kg} / \mathrm{kg}$ to $0.0050 \mathrm{~kg} / \mathrm{kg}$, the room temperature and humidity ratio also decreased from $30.80^{\circ} \mathrm{C}$ to $28.22^{\circ} \mathrm{C}$ and from $0.0152 \mathrm{~kg} / \mathrm{kg}$ to $0.0115 \mathrm{~kg} / \mathrm{kg}$, respectively. The COP decreased from 0.65 to 0.57 . The set point of $0.0050 \mathrm{~kg} / \mathrm{kg}$ humidity ratio in comparison with another set point thus leads the system to reach near thermal comfort conditions.

By comparing the temperature results of the one-stage ventilation and recirculation in each humidity ratio set point, the regeneration temperature under the ventilation mode is found to be considerably higher than that under the recirculation mode. The temperatures of the supply air under 


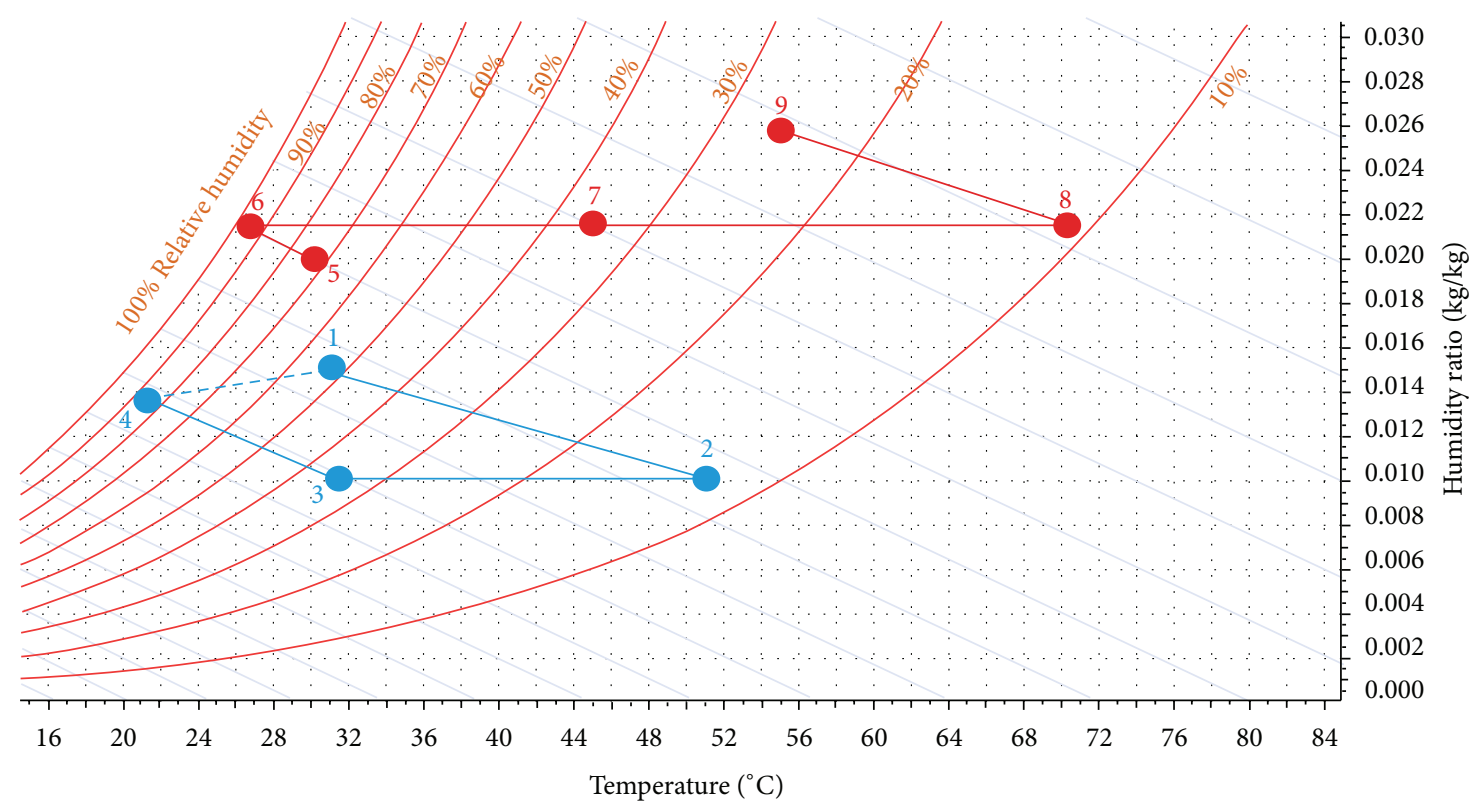

FIGURE 10: Psychometric chart of one-stage solar desiccant cooling system in recirculation mode.

TABLE 4: Air properties results of ventilation and recirculation modes based on different humidity ratio set points.

\begin{tabular}{|c|c|c|c|c|c|c|c|c|c|c|c|c|}
\hline \multirow{3}{*}{$\begin{array}{l}\text { Humidity ratio } \\
\text { set point } \\
(\mathrm{kg} / \mathrm{kg})\end{array}$} & \multicolumn{6}{|c|}{ Ventilation mode } & \multicolumn{6}{|c|}{ Recirculation mode } \\
\hline & \multirow{2}{*}{$\operatorname{Reg} T\left({ }^{\circ} \mathrm{C}\right)$} & \multicolumn{2}{|r|}{ SA } & \multirow[b]{2}{*}{$T\left({ }^{\circ} \mathrm{C}\right)$} & \multirow{2}{*}{$\begin{array}{l}\text { RA } \\
\mathrm{HR}(\mathrm{kg} / \mathrm{kg})\end{array}$} & \multirow{2}{*}{$\mathrm{COP}$} & \multirow{2}{*}{$\operatorname{Reg} T\left({ }^{\circ} \mathrm{C}\right)$} & \multicolumn{2}{|r|}{ SA } & \multirow[b]{2}{*}{$T\left({ }^{\circ} \mathrm{C}\right)$} & \multirow{2}{*}{$\begin{array}{l}\text { RA } \\
\text { HR }(\mathrm{kg} / \mathrm{kg})\end{array}$} & \multirow{2}{*}{$\mathrm{COP}$} \\
\hline & & $T\left({ }^{\circ} \mathrm{C}\right)$ & $\mathrm{HR}(\mathrm{kg} / \mathrm{kg})$ & & & & & $T\left({ }^{\circ} \mathrm{C}\right)$ & $\mathrm{HR}(\mathrm{kg} / \mathrm{kg})$ & & & \\
\hline 0.0050 & 122.00 & 19.48 & 0.0100 & 28.22 & & 0.57 & 96.90 & 18.50 & 0.0100 & 28.50 & & 0.29 \\
\hline 0.0080 & 98.40 & 20.95 & 0.0121 & 30.24 & 0.0136 & 0.61 & 80.30 & 20.80 & 0.0121 & 30.46 & 0.0135 & 0.40 \\
\hline 0.0100 & 81.60 & 22.00 & 0.0137 & 30.80 & 0.0152 & 0.65 & 70.20 & 21.40 & 0.0136 & 31.00 & 0.0150 & 0.50 \\
\hline
\end{tabular}

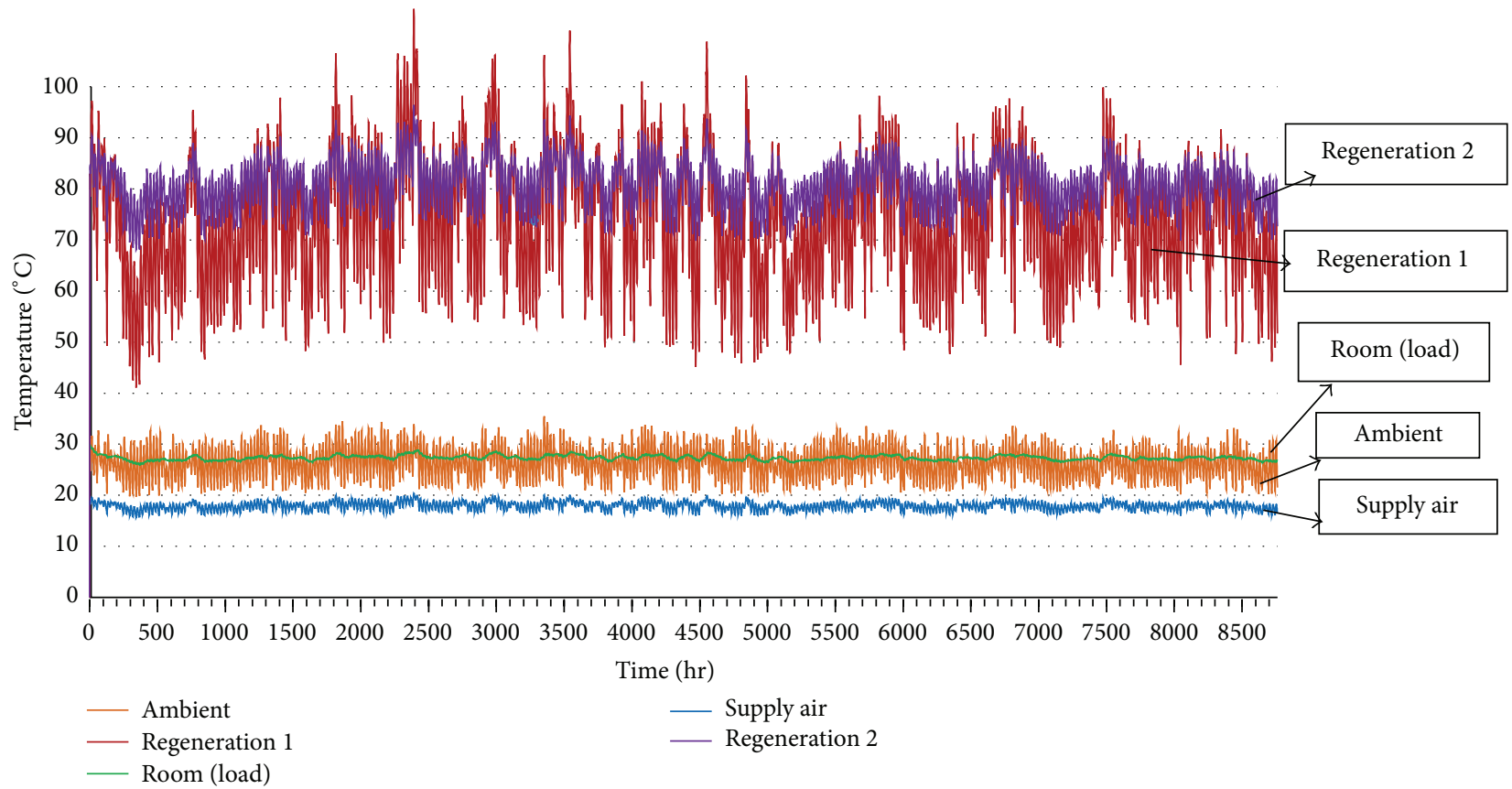

FIgURE 11: Temperatures $\left({ }^{\circ} \mathrm{C}\right)$ of different components versus time $(\mathrm{hr})$ in two-stage ventilation desiccant cooling system. 


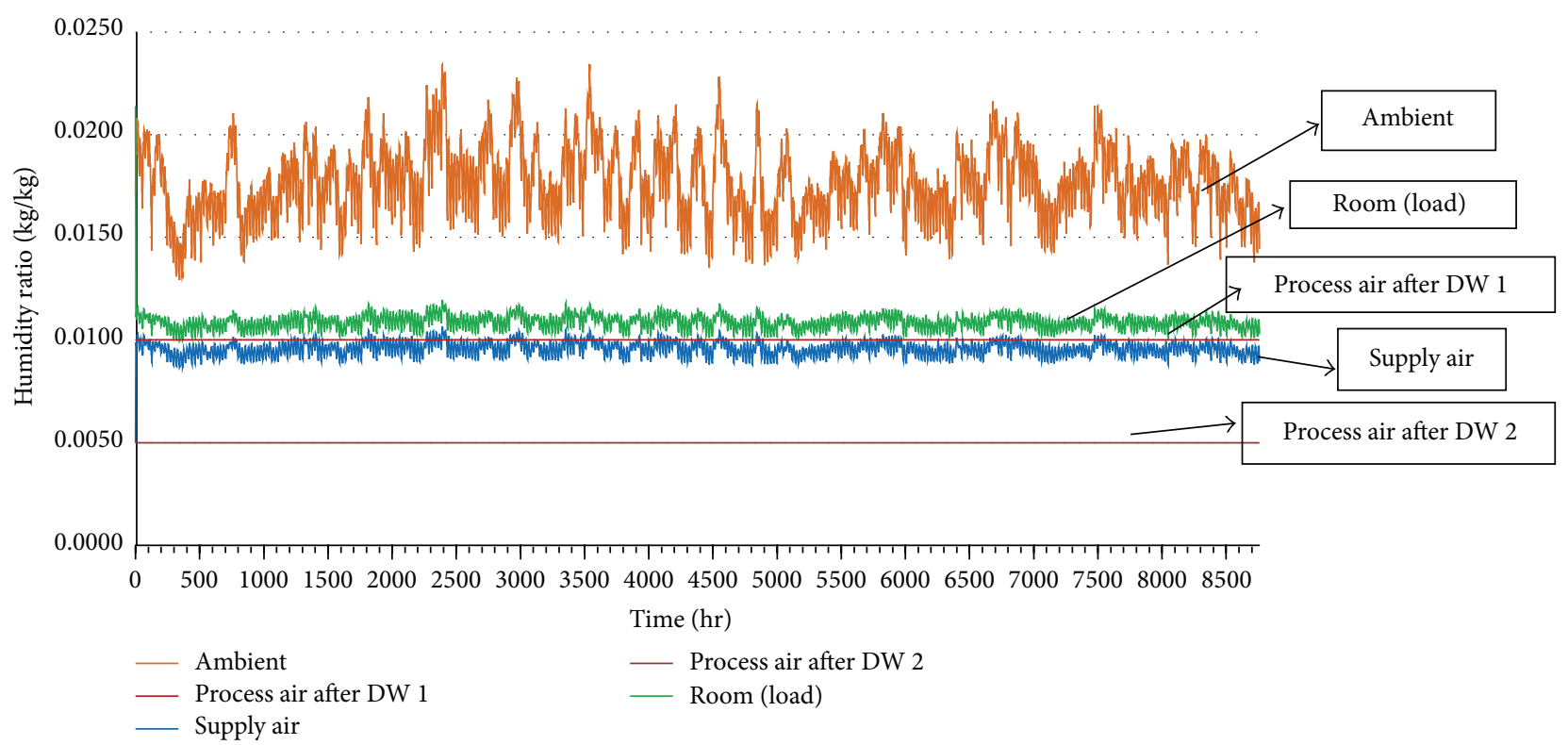

FIGURE 12: Humidity ratio $(\mathrm{kg} / \mathrm{kg})$ of different components versus time $(\mathrm{hr})$ in two-stage ventilation desiccant cooling system.

both modes are almost the same. In addition, the room temperatures under both modes are almost the same.

By comparison, the humidity ratio results of the ventilation and recirculation show that the humidity ratio of the room and the supply air under both modes are almost the same. The COPs under the ventilation and recirculation modes are calculated using (1) and (2). Therefore, the COPs of the desiccant cooling system under the ventilation mode are higher than those under the recirculation mode.

\subsection{Result of the Two-Stage Solar Desiccant Cooling System.} The simulation results of the two-stage desiccant cooling system under the two modes of ventilation and recirculation are explained in the following sections.

3.3.1. Two-Stage Ventilation. Figure 11 shows the temperature trend in the different points of the two-stage solar desiccant system, such as the temperatures of the regeneration of the first and second DWs, room, ambient air, and supply air versus time (hr). The first and second regeneration temperatures are approximately $80^{\circ} \mathrm{C}$. The humidity ratio of the ambient air, process air after DW, room, and supply air versus time (hr) under the two-stage ventilation mode are shown in Figure 12.

The humidity ratios of the air after the first and second dehumidification are 0.0100 and $0.0050 \mathrm{~kg} / \mathrm{kg}$, respectively, during the $8,760 \mathrm{hr}$ system operation. According to the temperature and humidity ratio results under the ventilation mode, the important points of the air property are detected and shown in Table 5.

Figure 13 shows the psychometric chart of the two-stage solar desiccant cooling system under the ventilation mode. The process air side of this system includes the two-step dehumidification process ( 1 and 2 and 3 and 4 ) by the two DWs, the two-step cooling process (2 and 3 and 4 and 5)
TABLE 5: Air properties of two-stage solar desiccant cooling system in ventilation mode.

\begin{tabular}{lcc}
\hline Points number & Temperature $\left({ }^{\circ} \mathrm{C}\right)$ & Humidity ratio $(\mathrm{kg} / \mathrm{kg})$ \\
\hline 1 & 30 & 0.0200 \\
2 & 53.7 & 0.0100 \\
3 & 30.2 & 0.0100 \\
4 & 50 & 0.0050 \\
5 & 28.3 & 0.0050 \\
6 & 17.62 & 0.0096 \\
7 & 27.3 & 0.0109 \\
8 & 29.71 & 0.0145 \\
9 & 23.4 & 0.0168 \\
10 & 45.1 & 0.0168 \\
11 & 82.1 & 0.0168 \\
12 & 41.5 & 0.0270 \\
13 & 48.2 & 0.0168 \\
14 & 80 & 0.0168 \\
15 & 34 & 0.0280 \\
\hline
\end{tabular}

by the two heat recovery wheels, and the one-stage cooling process (5 and 6) by the evaporative cooler. The process from points 1 to 5 is defined as isothermal dehumidification. The regeneration air side includes a few processes such as the mixing of ambient air and returning air process (7 and 8 ), evaporative cooling process ( 8 and 9 ), two-step heating process ( 9 and 10 and 9-13) by the heat recovery wheels, twostep heating process (10 and 11 and 13 and 14) by the solar heater, and two-step process of exhausted air outdoors (11 and 12 and 14 and 15).

3.3.2. Two-Stage Recirculation. The temperature trend in various points in the two-stage recirculation solar desiccant 


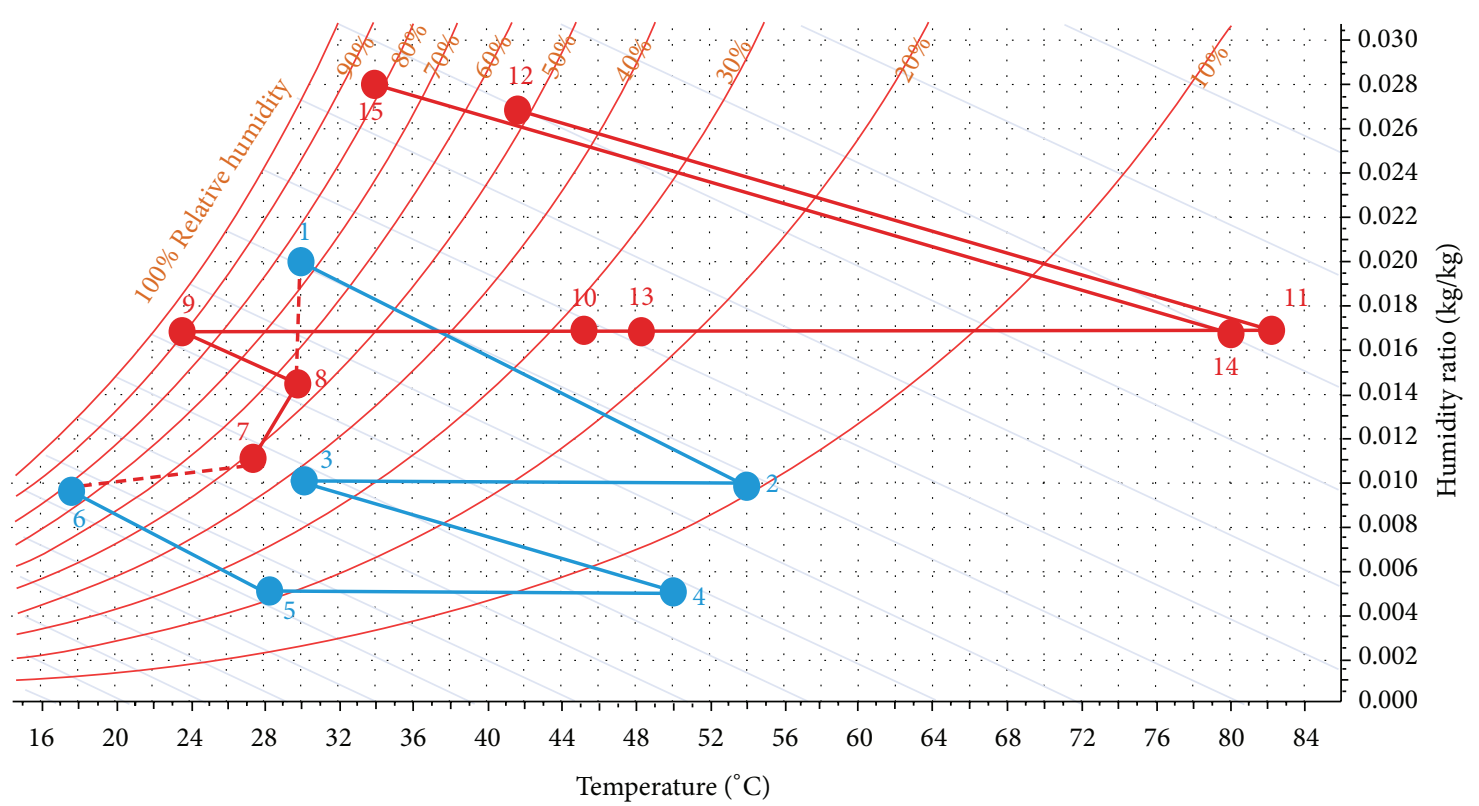

FIGURE 13: Psychometric chart of two-stage solar desiccant cooling system in ventilation mode.

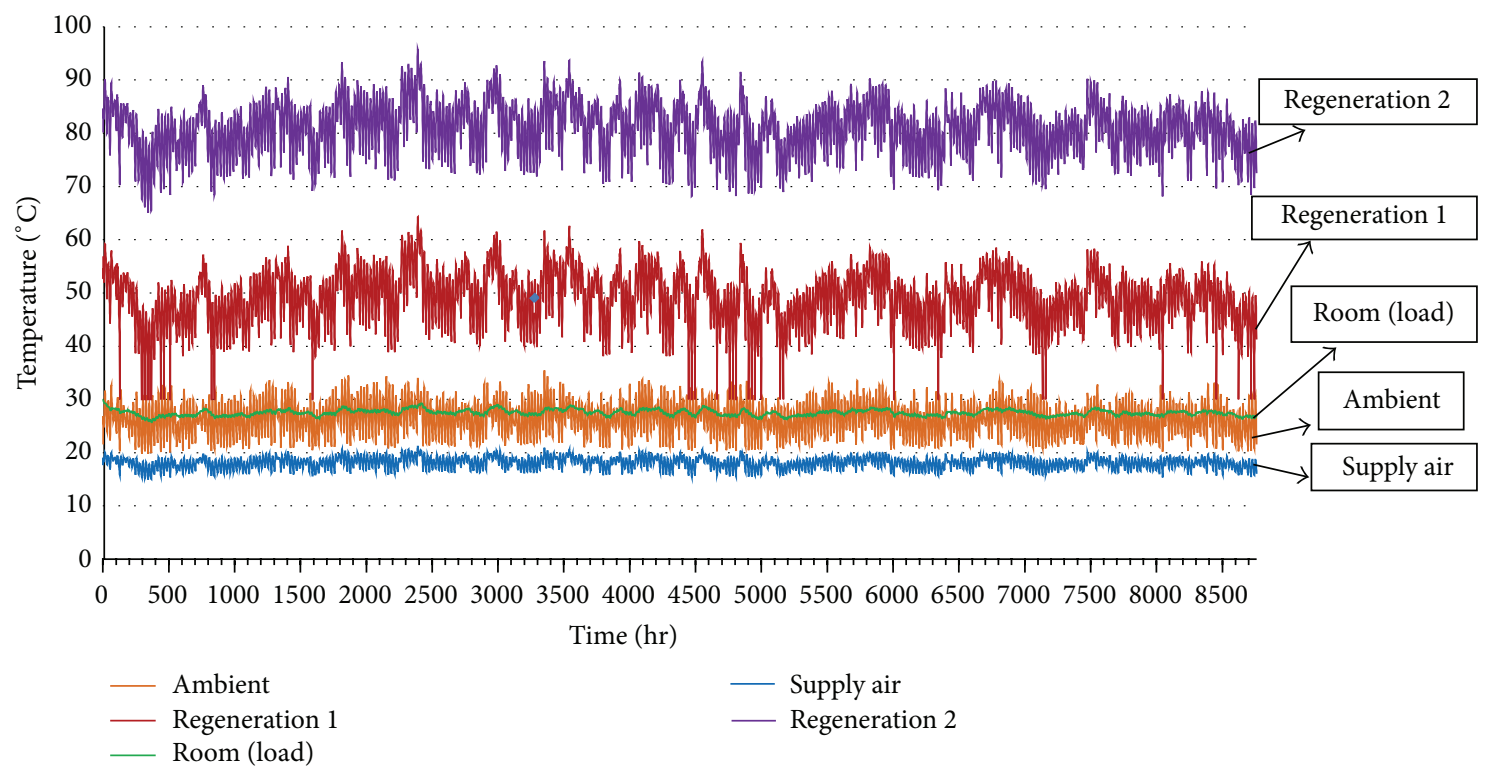

Figure 14: Temperatures $\left({ }^{\circ} \mathrm{C}\right)$ of different components versus time (hr) in two-stage recirculation desiccant cooling system.

cooling system versus time (hr) is shown in Figure 14. The humidity ratio trend of the various points in the two-stage recirculation system versus time (hr) is shown in Figure 15. According to the temperature and humidity ratio results of the simulation model of the two-stage system under the recirculation mode, the important points of air properties are detected and shown in Table 6.

Figure 16 shows the psychometric chart of the two-stage solar desiccant cooling system under the recirculation mode. The process air side of this system includes several processes such as the returning air process from the room to the first DW (6-1), two-step dehumidification process (1 and 2 and
3 and 4 ) by the two DWs, two-step cooling process (2 and 3 and 4 and 5) by the two heat recovery wheels, and onestage cooling process ( 5 and 6 ) by the evaporative cooler. The regeneration air side includes several processes such as the evaporative cooling process (7 and 8), two-step heating process (8 and 9 and 8-12) by the heat recovery wheel, twostep heating process ( 9 and 10 and 12 and 13) by the solar heater, and two-step process of exhausted air to outdoor (10 and 11 and 13 and 14).

3.4. Comparison Results between the Two-Stage Ventilation and Recirculation Modes. The humidity ratios of the process 


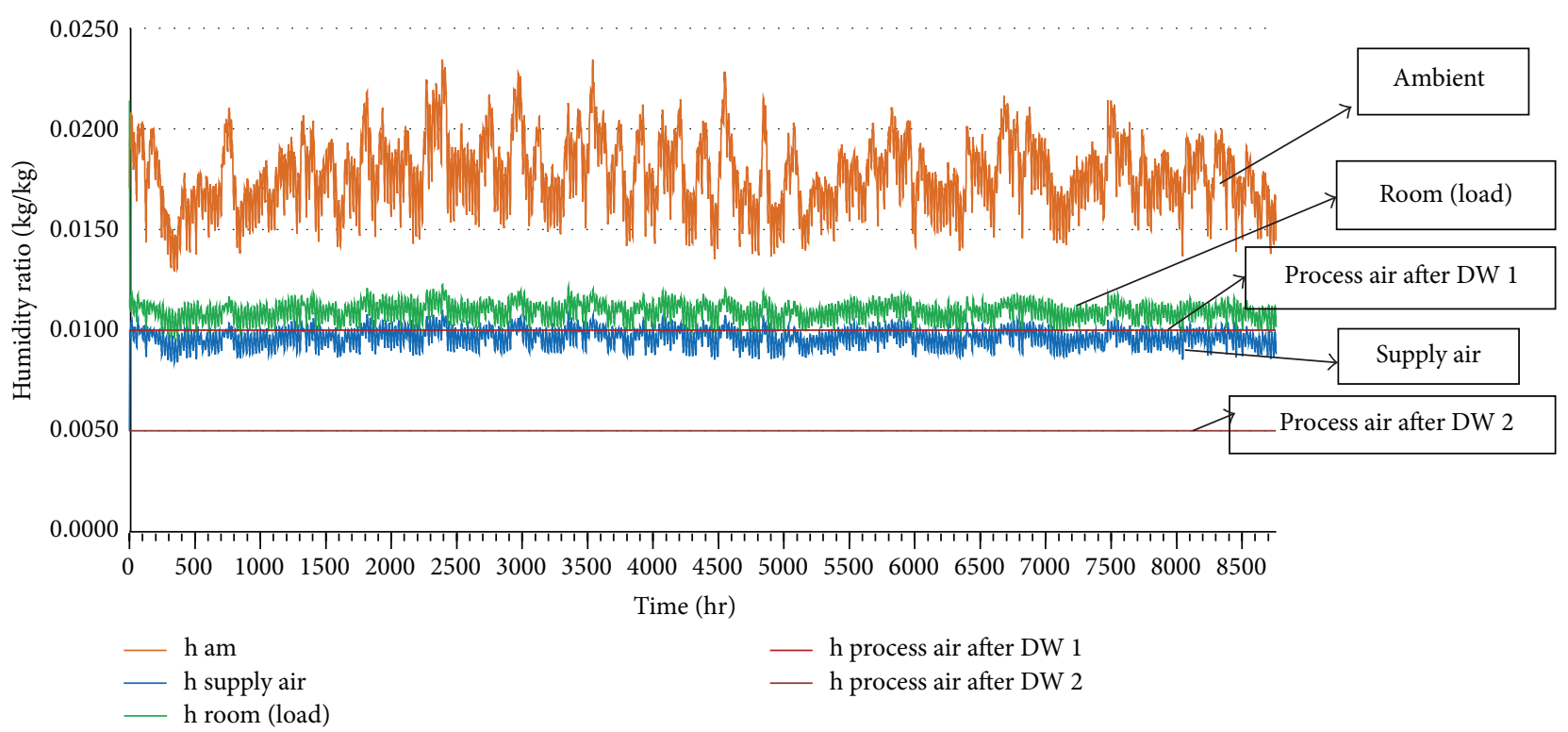

FIGURE 15: Humidity ratio $(\mathrm{kg} / \mathrm{kg})$ of different components versus time (hr) in two-stage recirculation mode.

TABLE 6: Air properties of two-stage solar desiccant cooling system in recirculation mode.

\begin{tabular}{lcc}
\hline Points number & Temperature $\left({ }^{\circ} \mathrm{C}\right)$ & Humidity ratio $(\mathrm{kg} / \mathrm{kg})$ \\
\hline 1 & 27 & 0.0109 \\
2 & 34.82 & 0.0100 \\
3 & 27.3 & 0.0100 \\
4 & 49.33 & 0.0050 \\
5 & 30.74 & 0.0050 \\
6 & 18 & 0.0096 \\
7 & 30 & 0.0200 \\
8 & 26.1 & 0.0211 \\
9 & 41.3 & 0.0211 \\
10 & 80 & 0.0211 \\
11 & 58.7 & 0.0253 \\
12 & 32.9 & 0.0211 \\
13 & 50 & 0.0211 \\
14 & 42.6 & 0.0231 \\
\hline
\end{tabular}

air after the first and second DWs under both modes are 0.0100 and $0.0050 \mathrm{~kg} / \mathrm{kg}$, respectively. By comparing the temperature results of the two-stage ventilation and recirculation modes, the regeneration temperatures under the ventilation mode are found to be higher than those under the recirculation mode. The supply air temperature and humidity ratio under the ventilation mode are $17.6^{\circ} \mathrm{C}$ and $0.0096 \mathrm{~kg} / \mathrm{kg}$, respectively, whereas those under the recirculation mode are $18^{\circ} \mathrm{C}$ and $0.0096 \mathrm{~kg} / \mathrm{kg}$, respectively. The room air temperature and humidity ratio are $27.3^{\circ} \mathrm{C}$ and $0.0109 \mathrm{~kg} / \mathrm{kg}$, respectively, whereas those under the recirculation mode are $27^{\circ} \mathrm{C}$ and $0.0109 \mathrm{~kg} / \mathrm{kg}$, respectively. The COPs under the ventilation and recirculation modes are calculated by (3) and (4). The COPs of the ventilation and recirculation are 1.06 and 0.43 , respectively. Although the cooling system driving energy in ventilation mode was higher than the recirculation mode, the rate of cooling capacity in ventilation mode was higher than the recirculation mode. The COPs of the one-stage and two-stage desiccant cooling systems under the ventilation mode were higher than those under the recirculation mode.

3.5. Comparison Results of the Four Configurations of the Solar Desiccant Cooling Systems. The regeneration temperature, supply air temperature, supply air relative humidity, supply air humidity ratio, room air temperature, room air relative humidity, room air humidity ratio, COP, and solar fraction of the four configurations of the solar desiccant cooling are shown in Table 7 . The values are average for one year. The final humidity ratio set point before the evaporative cooler for the four configurations is $0.005 \mathrm{~kg} / \mathrm{kg}$ humidity ratio. Whereas the one-stage desiccant cooling dehumidification occurs in one step, the two-stage desiccant cooling dehumidification occurs in two steps.

The supply and return air temperatures and humidity ratios of the two-stage system are less than those of the one-stage system. Regarding the thermal comfort condition parameters, the results of the two-stage desiccant cooling system were better than the one-stage desiccant cooling system. Given the isothermal dehumidificationin process in the two stage desiccant cooling systems, the regeneration temperature of the two-stage ventilation and recirculation was lower than the one stage ventilation and recirculation. By comparing the best configuration of the one-stage and twostage ventilation modes, the two-stage ventilation solar cooling system was selected as the best configuration among the four configurations because of its higher COP, as well as lower room temperature and humidity ratio. By comparing the 


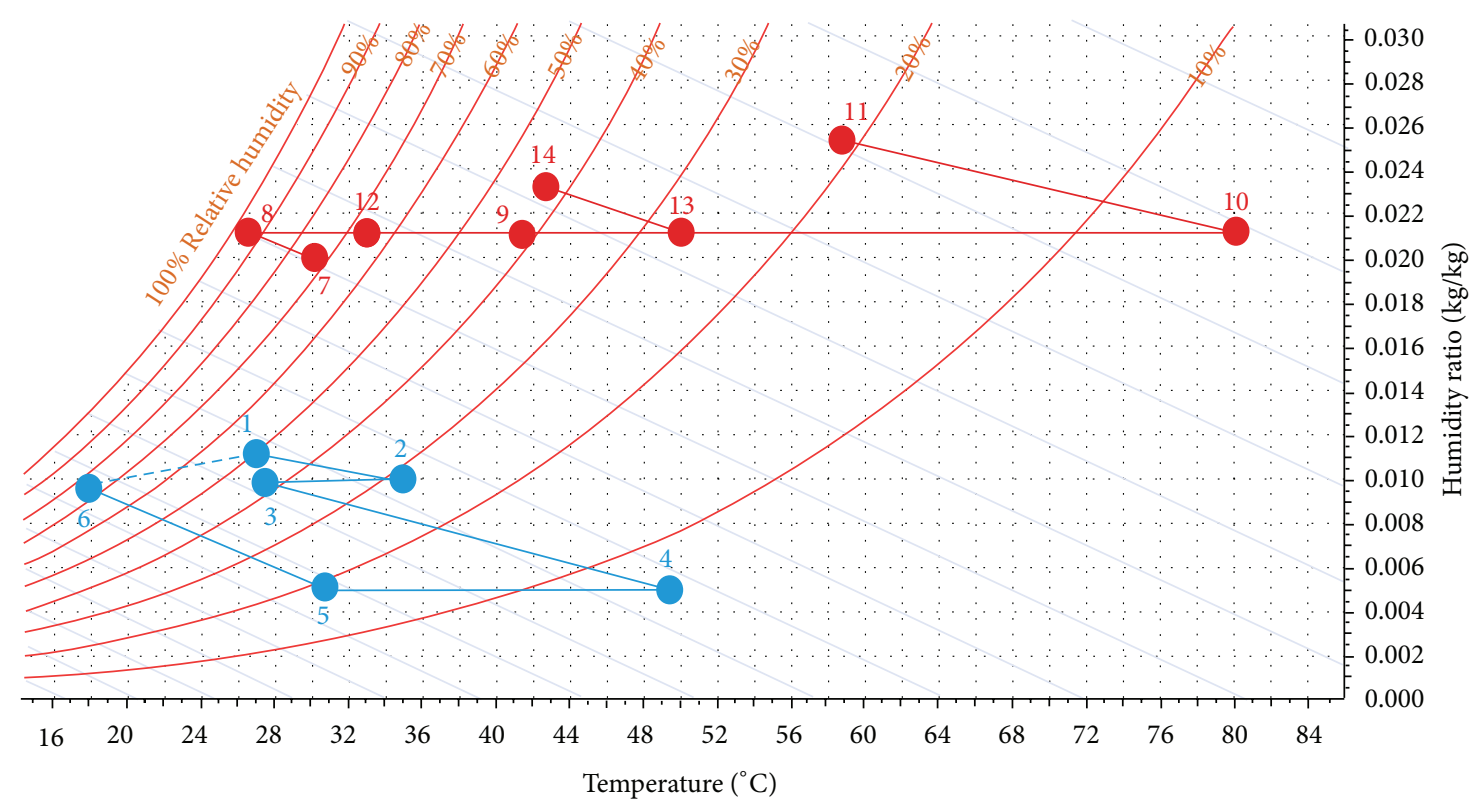

FIGURE 16: Psychometric chart of two-stage solar desiccant cooling system in recirculation mode.

TABle 7: Performance comparison of four desiccant cooling configurations under $0.005 \mathrm{~kg} / \mathrm{kg}$ humidity ratio set point in hot and humid climate $\left(30^{\circ} \mathrm{C}, 20 \mathrm{HR}\right)$.

\begin{tabular}{|c|c|c|c|c|c|c|c|c|c|}
\hline \multirow{2}{*}{ Type of configurations } & \multirow{2}{*}{$T \operatorname{reg}\left({ }^{\circ} \mathrm{C}\right)$} & \multicolumn{3}{|c|}{ SA } & \multicolumn{3}{|c|}{ RA } & \multirow{2}{*}{ COP } & \multirow{2}{*}{ SF $(\%)$} \\
\hline & & $T\left({ }^{\circ} \mathrm{C}\right)$ & $\mathrm{HR}(\mathrm{kg} / \mathrm{kg})$ & RH (\%) & $T\left({ }^{\circ} \mathrm{C}\right)$ & $\mathrm{HR}(\mathrm{kg} / \mathrm{kg})$ & $\mathrm{RH}(\%)$ & & \\
\hline One-stage ventilation & 122.00 & 19.48 & 0.0100 & 70.4 & 28.22 & 0.0115 & 47.9 & 0.57 & 39 \\
\hline One-stage recirculation & 96.90 & 18.50 & 0.0100 & 75.0 & 28.50 & 0.0115 & 47.1 & 0.29 & 50 \\
\hline Two-stage ventilation & $82.10-80.00$ & 17.60 & 0.0096 & 76.2 & 27.30 & 0.0109 & 48.0 & 1.06 & 69 \\
\hline Two-stage recirculation & $80.00-50.00$ & 18.00 & 0.0096 & 74.3 & 27.00 & 0.0109 & 48.7 & 0.43 & 85 \\
\hline
\end{tabular}

solar fractions of the four configurations, the solar fraction percentage for the two-stage ventilation desiccant cooling system was $69 \%$. The maximum and minimum solar fractions were for the two-stage recirculation and one-stage ventilation systems.

\section{Conclusions}

This paper has presented a comparison study among four configurations of a solar desiccant cooling system in the hot and humid weather in Malaysia. The four systems, namely, the one-stage ventilation, one-stage recirculation, two-stage ventilation, and two-stage recirculation, were simulated during an $8,760 \mathrm{hr}$ operation by TRNSYS. The COP of the twostage ventilation mode was higher than those of the other configurations. The two-stage ventilation produced supply air at $17.6^{\circ} \mathrm{C}$ and $0.0096 \mathrm{~kg} / \mathrm{kg}$ to remove the sensible load of the room, whereas the supply air temperatures of the other configurations were higher. Therefore, based on the condition of ambient air $\left(30^{\circ} \mathrm{C}\right.$ and $\left.0.0200 \mathrm{~kg} / \mathrm{kg}\right)$, the two-stage solar desiccant cooling system under the ventilation mode is more suitable than the other configurations.

\section{Nomenclature}

A: $\quad$ Collector area $\left[\mathrm{m}^{2}\right]$

AC: $\quad$ Air conditioning system [-]

ASHRAE: American Society of Heating, Refrigerating and Air Conditioning Engineers [-]

COP: Thermal coefficient of performance [-]

DEC: $\quad$ Direct evaporative cooler [-]

DW: Desiccant wheel [-]

F1, F2: $\quad$ Effectiveness of desiccant wheel

G: $\quad$ Solar radiation $\left[\mathrm{W} / \mathrm{m}^{2}\right]$

$h: \quad$ Enthalpy $[\mathrm{kj} / \mathrm{kg}]$

hr: Time [hour]

HR: $\quad$ Humidity ratio $[\mathrm{kg} / \mathrm{kg}]$

HRW: $\quad$ Heat recovery wheel [-]

HVAC: Heating, Ventilation, and Air-Conditioning $[-]$

HX: $\quad$ Heat exchanger [-]

$Q_{\text {cool }}: \quad$ Cooling capacity of the system $[\mathrm{kW}]$

$Q_{T}: \quad$ The cooling system driving energy

$Q_{U}: \quad$ Solar thermal power $[\mathrm{kW}]$

reg: Regeneration

RA: $\quad$ Return air [-]

SA: $\quad$ Supply air [-] 


\author{
SF: $\quad$ Solar fraction [\%] \\ T: $\quad$ Air temperature $\left[{ }^{\circ} \mathrm{C}\right]$ \\ TSRDC: Two-stage rotary desiccant cooling [-] \\ $\dot{m}_{s}$ : Mass flow rate of the supply air $[\mathrm{kg} / \mathrm{hr}]$ \\ $\dot{m}_{r}$ : Mass flow rate of regeneration air $[\mathrm{kg} / \mathrm{hr}]$ \\ $\eta: \quad$ Solar collector efficiency [-].
}

\section{Conflict of Interests}

The authors of the paper do not have any financial relation with the TRNSYS software company. They confirm that the paper is just a research workwhich has no financial benefit from TRNSYS Company or other companies.

\section{Acknowledgment}

The authors would like to thank the Solar Energy Research Institute (SERI), Universiti Kebangsaan Malaysia, for providing the laboratory facilities and technical support.

\section{References}

[1] D. La, Y. J. Dai, Y. Li, R. Z. Wang, and T. S. Ge, "Technical development of rotary desiccant dehumidification and air conditioning: a review," Renewable and Sustainable Energy Reviews, vol. 14, no. 1, pp. 130-147, 2010.

[2] E. Hürdoğan, O. Büyükalaca, T. Yılmaz, and A. Hepbaşl1, "Experimental investigation of a novel desiccant cooling system," Energy and Buildings, vol. 42, no. 11, pp. 2049-2060, 2010.

[3] A. Y. T. Al-Zubaydi, "Solar air conditioning and refrigeration with absorption chillers technology in australia-an overview on researches and applications," Journal of Advanced Science and Engineering Research, vol. 1, no. 1, pp. 23-41, 2011.

[4] K. Daou, R. Z. Wang, and Z. Z. Xia, "Desiccant cooling air conditioning: a review," Renewable and Sustainable Energy Reviews, vol. 10, no. 2, pp. 55-77, 2006.

[5] K. Haddad, B. Ouazia, and H. Barhoun, "Simulation of a desiccant-evaporative cooling system for residential buildings," in Proceedings of the 3rd Canadian Solar Building Conference, pp. 1-8, Fredericton, Canada, August 2008.

[6] K. F. Fong, V. I. Hanby, and T. T. Chow, "HVAC system optimization for energy management by evolutionary programming," Energy and Buildings, vol. 38, no. 3, pp. 220-231, 2006.

[7] M. M. Salehi Dezfouli, Z. Hashim, M. H. Ruslan, B. Bakhtyar, K. Sopian, and A. Zaharim, "Experimental investigation of solar hybrid desiccant cooling system in hot and humid weather of malaysia," in Proceedings of the 10th International Conference on Environment, Ecosystems and Development (WSEAS '12), 2012.

[8] S. Jain, P. L. Dhar, and S. C. Kaushik, "Evaluation of soliddesiccant-based evaporative cooling cycles for typical hot and humid climates," International Journal of Refrigeration, vol. 18, no. 5, pp. 287-296, 1995.

[9] P. Bourdoukan, E. Wurtz, and P. Joubert, "Comparison between the conventional and recirculation modes in desiccant cooling cycles and deriving critical efficiencies of components," Energy, vol. 35, no. 2, pp. 1057-1067, 2010.

[10] K. Mehmet, M. Özdinç Çarpınlıoğlu, and M. Yıldırım, "Energy and exergy analyses of an experimental open-cycle desiccant cooling system," Applied Thermal Engineering, vol. 24, no. 5-6, pp. 919-932, 2004.
[11] G. Panaras, E. Mathioulakis, and V. Belessiotis, "Achievable working range for solid all-desiccant air-conditioning systems under specific space comfort requirements," Energy and Buildings, vol. 39, no. 9, pp. 1055-1060, 2007.

[12] L. A. Sphaier and C. E. L. Nóbrega, "Parametric analysis of components effectiveness on desiccant cooling system performance," Energy, vol. 38, no. 1, pp. 157-166, 2012.

[13] Z. Huan and N. Jianlei, "Two-stage desiccant cooling system using low-temperature heat," Building Services Engineering Research and Technology, vol. 20, no. 2, pp. 51-55, 1999.

[14] Z. Q. Xiong, Y. J. Dai, and R. Z. Wang, "Development of a novel two-stage liquid desiccant dehumidification system assisted by $\mathrm{CaCl} 2$ solution using exergy analysis method," Applied Energy, vol. 87, no. 5, pp. 1495-1504, 2010.

[15] S. Techajunta, S. Chirarattananon, and R. H. B. Exell, "Experiments in a solar simulator on solid desiccant regeneration and air dehumidification for air conditioning in a tropical humid climate," Renewable Energy, vol. 17, no. 4, pp. 549-568, 1999.

[16] K.-H. Yang and S.-H. Wang, "The analysis of a solar-assisted desiccant evaporative cooling system and its application," Journal of the Chinese Institute of Engineers, vol. 11, no. 3, pp. 227234, 1988.

[17] G. Meckler, "Two-stage desiccant dehumidification in commercial building HVAC systems," Ashrae Transactions, vol. 95, no. 2, pp. 1116-1123, 1989.

[18] H.-M. Henning, "Solar assisted air conditioning of buildingsan overview," Applied Thermal Engineering, vol. 27, no. 10, pp. 1734-1749, 2007.

[19] D. La, Y. Dai, Y. Li, T. Ge, and R. Wang, "Case study and theoretical analysis of a solar driven two-stage rotary desiccant cooling system assisted by vapor compression air-conditioning," Solar Energy, vol. 85, no. 11, pp. 2997-3009, 2011.

[20] T. S. Ge, Y. Li, R. Z. Wang, and Y. J. Dai, "Experimental study on a two-stage rotary desiccant cooling system," International Journal of Refrigeration, vol. 32, no. 3, pp. 498-508, 2009.

[21] D. La, Y. Li, Y. J. Dai, T. S. Ge, and R. Z. Wang, "Development of a novel rotary desiccant cooling cycle with isothermal dehumidification and regenerative evaporative cooling using thermodynamic analysis method," Energy, vol. 44, no. 1, pp. 778-791, 2012.

[22] H. Li, Y. J. Dai, Y. Li, D. La, and R. Z. Wang, "Case study of a two-stage rotary desiccant cooling/heating system driven by evacuated glass tube solar air collectors," Energy and Buildings, vol. 47, pp. 107-112, 2012.

[23] H. Li, Y. J. Dai, Y. Li, D. La, and R. Z. Wang, "Experimental investigation on a one-rotor two-stage desiccant cooling/heating system driven by solar air collectors," Applied Thermal Engineering, vol. 31, no. 17-18, pp. 3677-3683, 2011.

[24] ASHRAE Handbook-HVAC Systems and Equipment, American Society of Heating, Refrigerating, and Air Conditioning Engineers, Atlanta, Ga, USA, 1996.

[25] A. M. Baniyounes, G. Liu, M. G. Rasul, and M. M. K. Khan, "Analysis of solar desiccant cooling system for an institutional building in subtropical Queensland, Australia," Renewable and Sustainable Energy Reviews, vol. 16, no. 8, pp. 6423-6431, 2012.

[26] Solar-Assisted Air-Conditioning in Buildings: A Handbook For Planners, Springer, New York, NY, USA, 2004. 

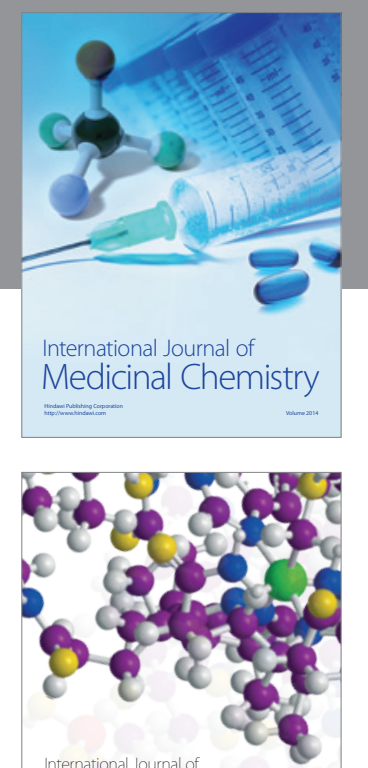

\section{Carbohydrate} Chemistry

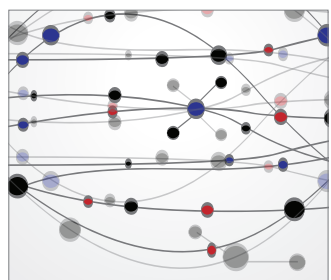

The Scientific World Journal
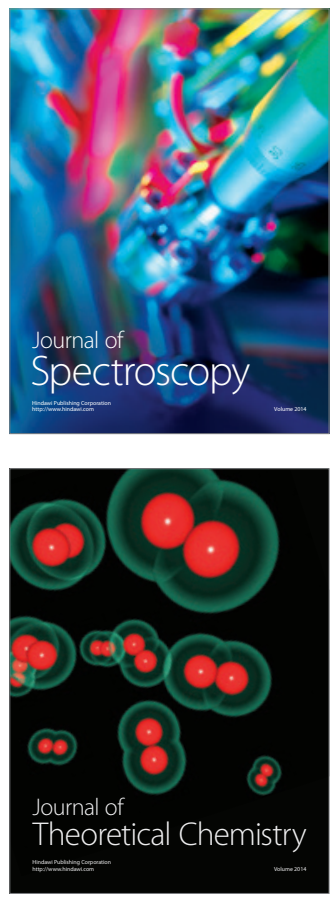
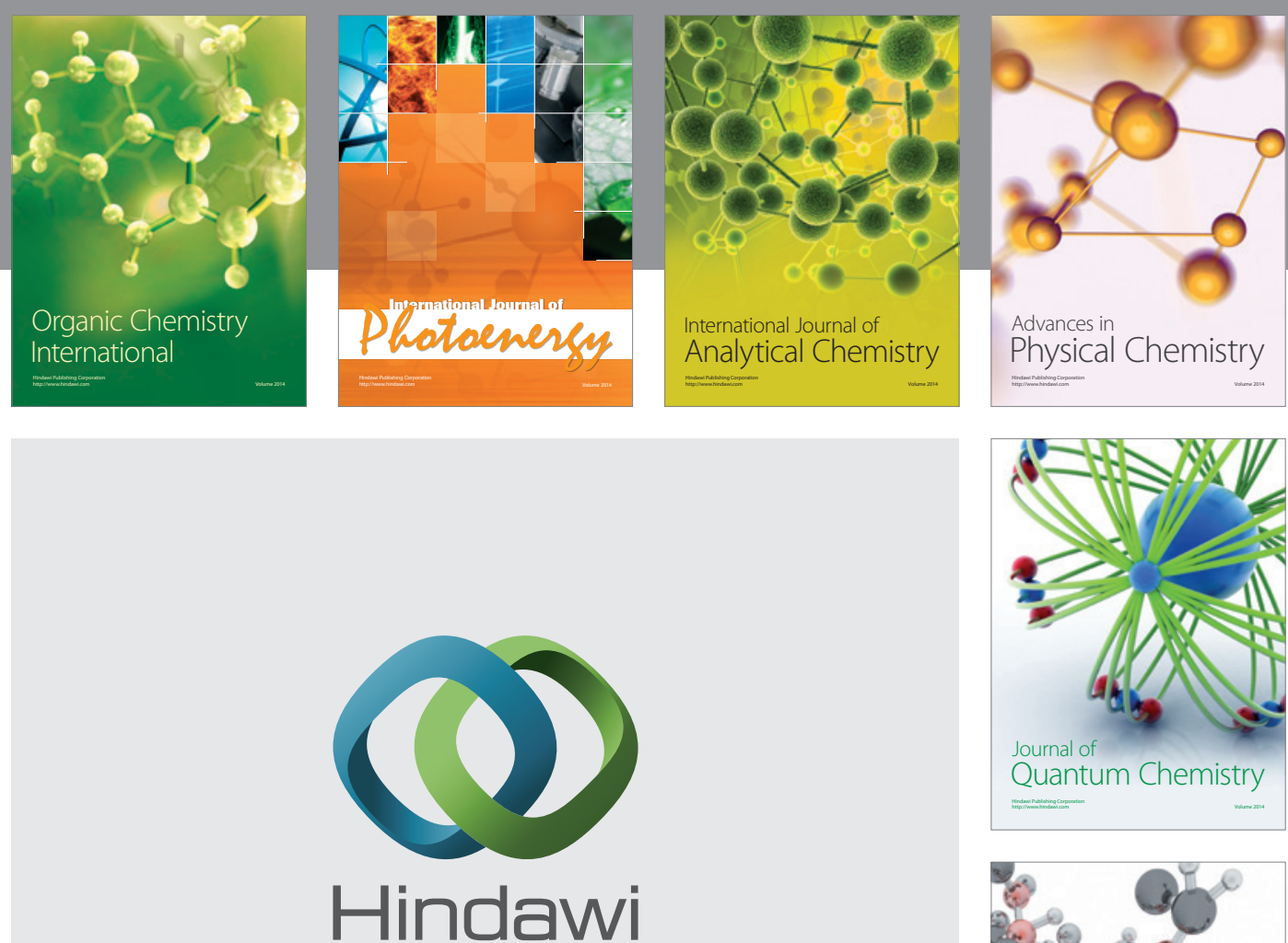

Submit your manuscripts at

http://www.hindawi.com

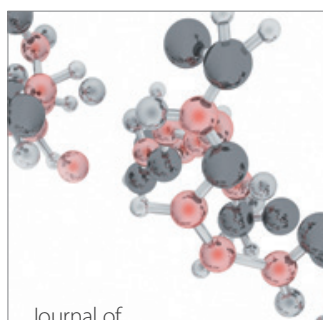

Analytical Methods

in Chemistry

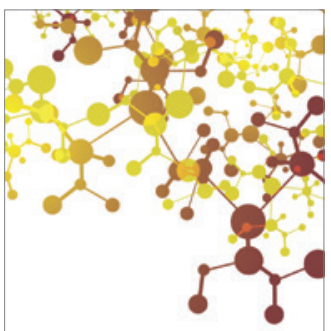

Journal of

Applied Chemistry

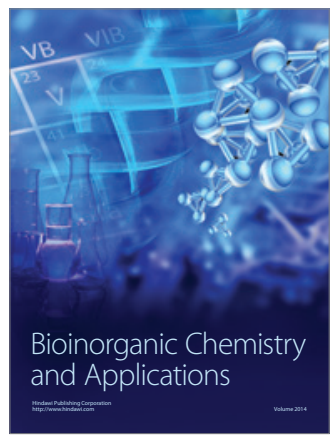

Inorganic Chemistry
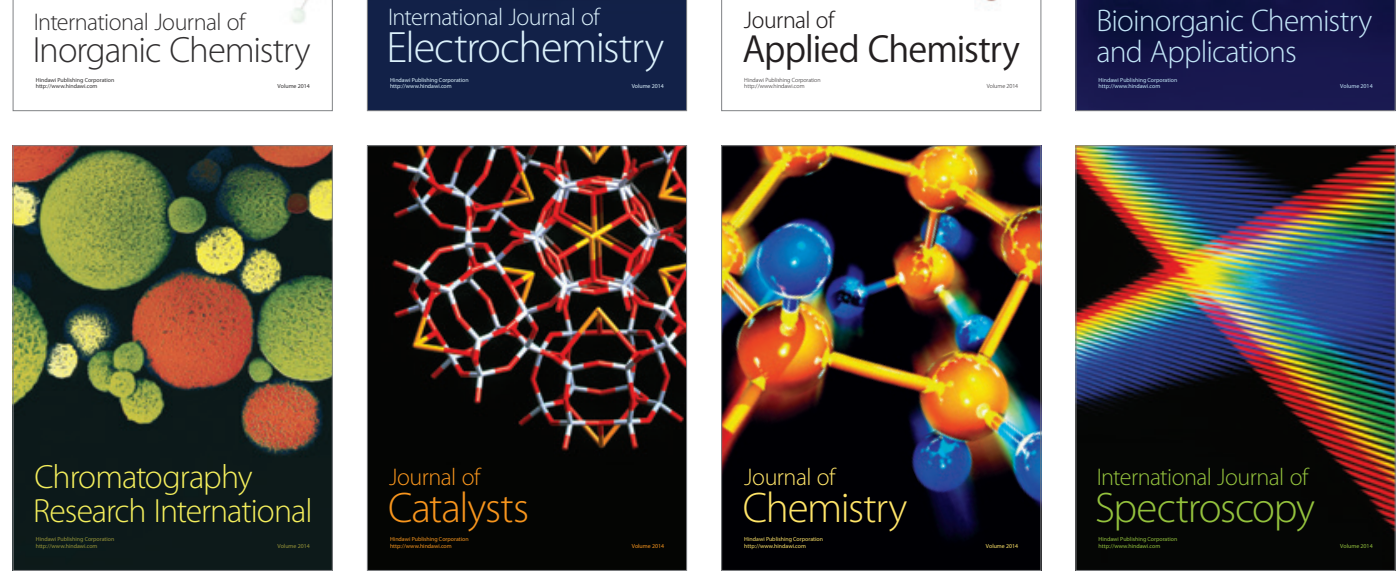